\title{
$e_{10^{2}}^{M}$
}

EEG-54

गया

.

PREOPERATIONAL RADIATION SURVEILLANCE

OF THE WIPP PROJECT BY EEG DURING 1992

Jim W. Kenney

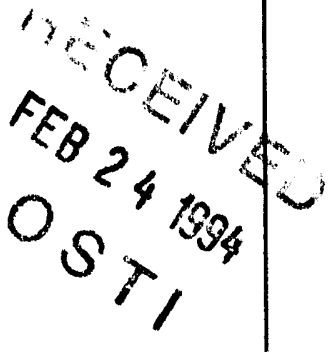

Environmental Evaluation Group

New Mexico

February 1994 
EEG-1 Goad, Donna, A Compilation of Site Selection Criteria Considerations and Concerns Appearing in the Literature on the Deep Disposal of Radioactive Wastes, June 1979.

EEG-2 Review Comments on Geological Charactrrization Report waste Isolation Pilot Plant (WIPP) Site, Southeastern New Mexico SAND 78-1596, Volume I and II, December 1978.

EEG-3 Nei11, Robert H., et al., (eds.) Radiological Health Review of the Draft Environmental Impact Statement (DOE/EIS-0026-D) Waste Isolation Filot Plant, U.S. Department of EnergY. August 1979.

EEG-4

Little, Marshall S., Review Comments on the Report of the Steering Committee on Waste Acceptance Criteria for the Waste Isolation Pilot Plant, February 1980.

EEG-5

Channe11, James K., Calculated Radiation Doses From Deposition of Material Released in Hypothetical Transportation Accidents Involving WIPP-Related Radioactive Wastes, October 1980.

EEG-6

Geotechnical Considerations for Radiological Hazard Assessment of WIPP. A Report of a Meeting Held on January $17-18,1980$, April 1980 .

EEG-7 Chaturvedi, Lokesh, WIPP Site and Vicinity Geological Field Trip. A Report of a Field Trip to the Proposed Waste Isolation Pilot Plant Project in Southeastern New Mexico. June 16 to 18 , 1980, October 1980 .

EEG-8 Wofsy, Carla, The Significance of Certain Rustler Aquifer Parameters for Predicting Long-Term Radiation Doses from WIPP, September 1980.

EEG-9 Spiegler, Peter, An Approach to Calculating Upper Bounds on Maximum Individual Doses From the Use of Contaminated Well Water Following a WIPP Repository Breach. September 1981.

EEG-10 Radiological Health Review of the Final Environmental Impact Statement (DOE/EIS-0026) Waste Isolation Pilot Plant, U.S. Department of Energy, January 1981.

EEG-11 Channe11, James K., Calculated Radiation Doses From Radionuclides Brought to the Surface if Future Drilling Intercepts the WIPP Repository and Pressurized Brine, January 1982.

EEG-12 Lıttle, Marshall S., Potential Release Scenario and Radiological Conseguence Evaluatlon of Mineral Resources at WIPP, May 1982 .

EEG-13 Spiegler, Peter, Analys is of the Potential Formation of a Breccia Chimey Beneath the WIPP Repository, May, 1982.

EEG-14 Not published.

EEG-15 Bard, Stephen T., Estimated Radiation Doses Resulting if an Exploratory Borehole Penetrates a Pressurized Brine Reservoir Assumed to Exist Below the WIPP Repository Horizon - A Single Hole Scenario, March 1982

EEG-16 Radionuclide Release. Transport and Consequence Modeling for WIPP. A Report of a Workshop Held on September $16-17,1981$, February 1982

EEG-17 Spiegler, Peter, Hydrologic Analyses of Two Brine Encounters in the Vicinity of the Waste Isolation Pilot Plant (WIPP) Site, December 1982.

EEG-18 Spiegler, Peter and Dave Updegraff, Origin of the Brines Near WIPP from the Dri11 Holes ERDA-6 and WIPP12 Based on Stable Isotope Concentration of Hydrogen and Oxysen, March 1983.

EEG-19 Channe11, James K., Review Comments on Environmental Analysis Cost Reduction Proposals (WIPP/DOE-136) July 1982, November 1982 .

EEG-20

Baca, Thomas E., An Evaluation of the Non-Radiological Environmental Problems Relating to the WIPP. February 1983.

EEG-21

Faith, Stuart, et al., The Geochemistry of Two Pressurized Brines From the Castile Formation in the Vicinity of the Waste Isolation Pilot Plant (WIPP) Site, April 1983.

EEG-22 EEG Review Comments on the Geotechnical Reports Provided by DOE to EEG Under the Stipulated ABreement Through March 1, 1983, Aprid 1983.

EEG-23 Nei11, Robert H., et a1., Evaluation of the Suitability of the WIPP Site, May 1983.

EEG-24 Nei11, Robert $H$, and James K. Channel1, Potential Problems From Shipment of High-Curie Content ContactHandled Transuranic (CH-TRU) Waste to WIPP, August 1983.

EEG-25

EEG-26

Chaturvedi, Lokesh, Occurrence of Gases in the Salado Formation, March 1984.

EEG-27

Spiegler, Peter, Proposed Preoperational Environmental Monitoring Program for WIPP. November 1984.

EEG -28

Rehfeldt, Kenneth, Sensitivity Analysis of Solute Transport in Fractures and Determination of Anisotropy Within the Culebra Dolomite, September 1984.

Knowles, H. B., Radiation Shielding in the Hot Cell Facility at the Waste Isolation Pilot Plant: A Review, November 1984 . 
EEG-54

DOE/AL/58309-54

Original Contract DE-AC04-79AL10752

\section{PREOPERATIONAL RADIATION SURVEILLANCE \\ OF THE WIPP PROJECT BY EEG DURING 1992}

Jim W. Kenney

Environmental Evaluation Group

P. O. Box 3149, 505 North Main Street

Carlsbad, New Mexico 88221

and

7007 Wyoming Boulevard NE, Suite F-2

Albuquerque, New Mexico 87109

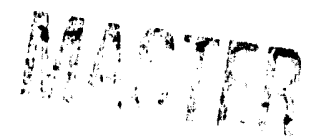

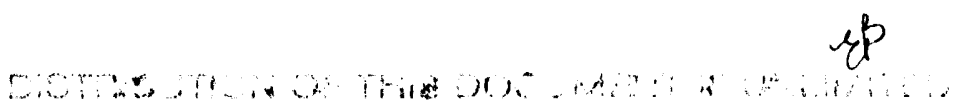

February 1994 


\section{FOREWORD}

The purpose of the New Mexico Environmental Evaluation Group (EEG) is to conduct an independent technical evaluation of the Waste Isolation Pilot Plant (WIPP) Project to ensure the protection of the public health and safety and the environment. The WIPP Project, located in southeastern New Mexico, is being constructed as a repository for the disposal of transuranic (TRU) radioactive wastes generated by the national defense programs. The EEG was established in 1978 with funds provided by the U. S. Department of Energy (DOE) to the State of New Mexico. Public Law 100-456, the National Defense Authorization Act, Fiscal Year 1989, Section 1433, assigned EEG to the New Mexico Institute of Mining and Technology and continued the original contract DE-AC0479AL10752 through DOE contract DE-ACO4-89AL58309. The National Defense Authorization Act for Fiscal Year 1994, Public Law 103-160, continues the authorization.

EEG performs independent technical analyses of the suitability of the proposed site; the design of the repository, its planned operation, and its long-term integrity; suitability and safety of the transportation systems; suitability of the Waste Acceptance Criteria and the generator sites' compliance with them; and related subjects. These analyses include assessments of reports issued by the DOE and its contractors, other federal agencies and organizations, as they relate to the potential health, safety and environmental impacts from WIPP. Another important function of EEG is the independent environmental monitoring of background radioactivity in air, water, and soil, both on-site and off-site.

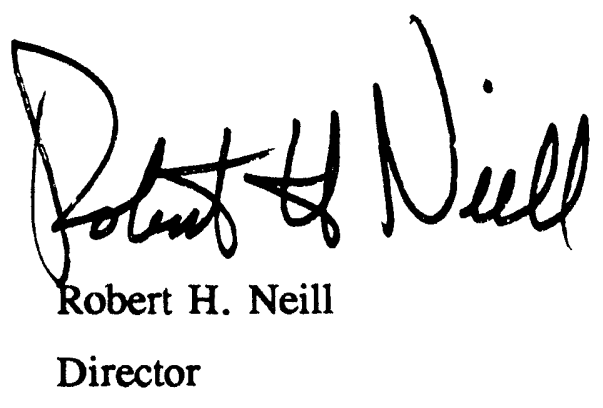

iii 


\section{EEG STAFF}

Sally C. Ballard, B.S., Laboratory Scientist

William T. Bartlett, Ph.D., Health Physicist

Radene Bradley, Secretary III

Lokesh Chaturvedi, Ph.D., Deputy Director \& Engineering Geologist

Patricia D. Fairchild, Secretary III

Daniel E. Fish, B.S., Assistant Environmental Technician

Donald H. Gray, M.A., Environmental Specialist

Jim W. Kenney, M.S., Environmental Scientist/Supervisor

Betsy J. Kraus, M.S., Technical Editor/Librarian

William W.-L. Lee, Sc.D., P.E., D.E.E., Senior Scientist

Robert H. Neill, M.S., Director

Jill Shortencarier, Administrative Secretary

Matthew K. Silva, Ph.D., Chemical Engineer

Susan Stokum, Administrative Secretary

Ben A. Walker, B.A., Environmental Technician

Ruth F. Weiner, Ph.D., Senior Scientist

Brenda J. West, B.A., Administrative Officer 


\section{TABLE OF CONTENTS}

\section{$\underline{\text { Page }}$}

FOREWORD $\ldots \ldots \ldots \ldots \ldots \ldots \ldots \ldots \ldots \ldots \ldots \ldots$ iii

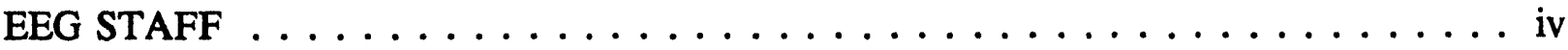

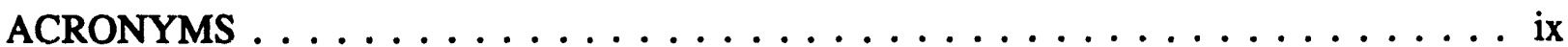

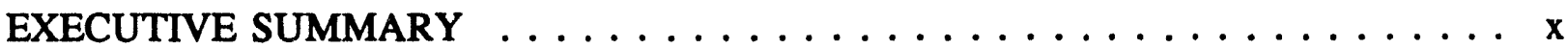

1.0 INTRODUCTION $\ldots \ldots \ldots \ldots \ldots \ldots \ldots \ldots \ldots \ldots \ldots$

2.0 ENVIRONMENTAL SETTING OF THE WIPP SITE $\ldots \ldots \ldots \ldots \ldots$

3.0 SUMMARY OF THE PREOPERATIONAL PROGRAM $\ldots \ldots \ldots \ldots$

3.1 Air Surveillance . . . . . . . . . . . . . . . . . . 9

3.2 Water Surveillance . . . . . . . . . . . . . . . . . . 15

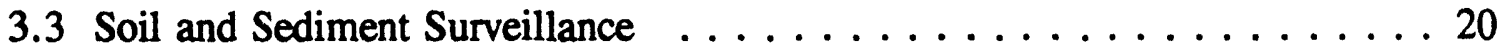

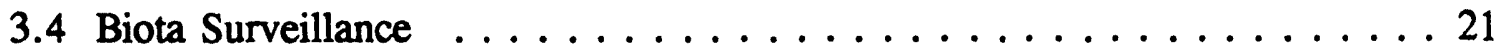

3.5 WIPP Effluent Surveillance . . . . . . . . . . . . . . 21

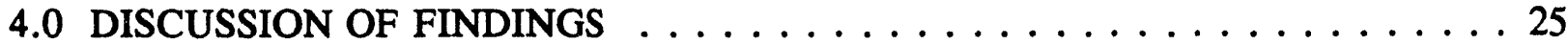

4.1 Air Data . . . . . . . . . . . . . . . . . 30

4.2 Water Data . . . . . . . . . . . . . . . . . . 31

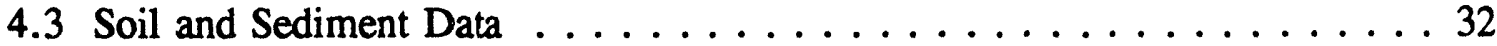

4.4 Biota Data . . . . . . . . . . . . . . . . . . . . 33

4.5 Station A Air Effluent $\ldots \ldots \ldots \ldots \ldots \ldots \ldots \ldots \ldots \ldots \ldots \ldots$

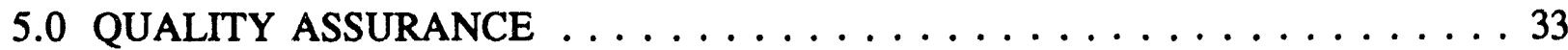

6.0 CONCLUSIONS AND RECOMMENDATIONS $\ldots \ldots \ldots \ldots \ldots$

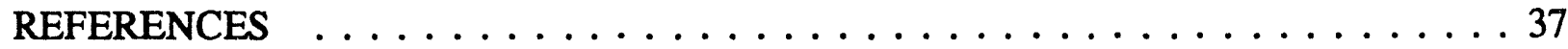

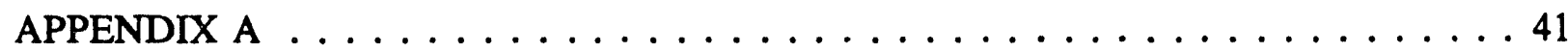

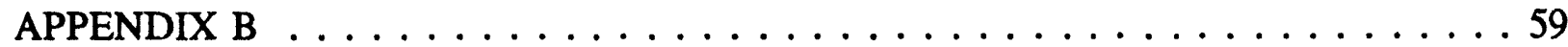




\section{LIST OF TABLES}

Page

TABLE 1. EEG Preoperational Radiological Surveillance Program . . . . . . . . 10

TABLE 2. Active Groundwater Sampling Locations . . . . . . . . . . . . . . 16

TABLE 3. Radionuclide LLD Data (Air Filters) $\ldots \ldots \ldots \ldots$

TABLE 4. Summary of Radiochemical Data Greater Than or Equal to LLD or

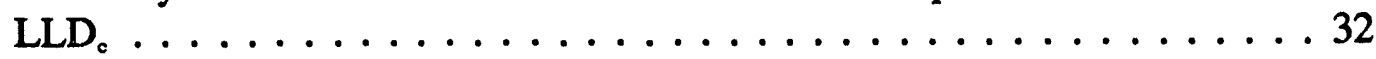

\section{LIST OF FIGURES}

\section{Page}

FIGURE 1. Location of the WIPP Site . . . . . . . . . . . . . . . 3

FIGURE 2. Nash Draw and Depressions Near the WIPP Site, Based on USGS Nash Draw Quadrangle, 15 Minute Series ... . . . . . . . . . . . 4

FIGURE 3. Zones at the WIPP Site ................... 6

FIGURE 4. Stratigraphy at the WIPP Site $\ldots \ldots \ldots \ldots \ldots \ldots$

FIGURE 5. Air Sampling Locations . . . . . . . . . . . . . . . . 12

FIGURE 6. Typical WIPP Site Low Volume Air Sampling Station (S-3) . . . . . 13

FIGURE 7. Typical Community Low Volume Air Sampling Station (Carlsbad) . . . 14

FIGURE 8. Groundwater Sampling Locations . . . . . . . . . . . . . . . 17

FIGURE $9 . \quad$ Surface Water Sampling Locations . . . . . . . . . . . . . . . . . . . 19

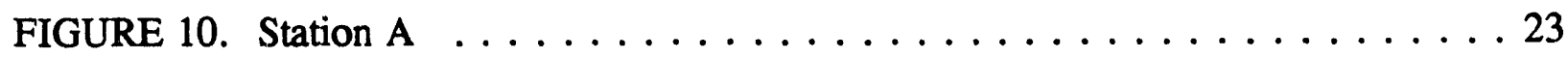

FIGURE 11. Locations of Station A and B . . . . . . . . . . . . . . 24 


\section{APPENDICES}

APPENDIX A:

TABLE A1. Radionuclide Data from Community Air Samples, First Quarter 1992 . 42

TABLE A2. Radionuclide Data from Community Air Samples, Second Quarter

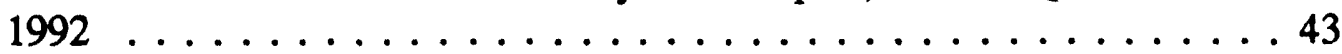

TABLE A3. Radionuclide Data from Community Air Samples, Third Quarter 1992 . 44

TABLE A4. Radionuclide Data from Community Air Samples, Fourth Quarter $1992 \ldots \ldots \ldots \ldots \ldots \ldots \ldots$

TABLE A5. Radionuclide Data from WIPP Site Air Samples, First Quarter 1992 . . 46

TABLE A6. Radionuclide Data from WIPP Site Air Samples, Second Quarter 1992 . 47

TABLE A7. Radionuclide Data from WIPP Site Air Samples, Third Quarter 1992 . . 48

TABLE A8. Radionuclide Data from WIPP Site Air Samples, Fourth Quarter 1992 . 49

TABLE A9. Radionuclide Data from I. IPP Underground Effluent Air Samples . . 50

TABLE A10. Radionuclide Data from Surface Water Samples . . . . . . . . . . 51

TABLE A11. Radionuclide Data from WIPP Effluent Water Samples . . . . . . . 55

TABLE A12. Radionuclide Data from Public Drinking Water Samples . . . . . . 56

TABLE A13. Radionuclide Data from Soil Samples $1992 \ldots \ldots$. . . . . . . . . . . . 58 
TABLES:

TABLE B1. $\quad$ LVAS Site: Artesia, New Mexico . . . . . . . . . . . . 60

TABLE B2. $\quad$ LVAS Site: Carlsbad, New Mexico .................61

TABLE B3. $\quad$ LVAS Site: Hobbs, New Mexico . . . . . . . . . . . . . 62

TABLE B4. LVAS Site: Loving, New Mexico ................ 63

TABLE B5. $\quad$ LVAS Site: WIPP - Site $1 \ldots \ldots \ldots$

TABLE B6. $\quad$ LVAS Site: WIPP - Site $2 \ldots \ldots \ldots 5$

TABLE B7. LVAS Site: WIPP - Site $3 \ldots \ldots 6$

\section{FIGURES:}

FIGURE B1. Net Alpha and Beta Activity-Artesia Air Samples-1992 . . . . . . . 67

FIGURE B2. Net Alpha and Beta Activity-Carlsbad Air Samples-1992 . . . . . . . 68

FIGURE B3. Net Alpha and Beta Activity-Hobbs Air Samples-1992 . . . . . . . 69

FIGURE B4. Net Alpha and Beta Activity-Loving Air Samples-1992 . . . . . . . . 70

FIGURE B5. Net Alpha and Beta Activity-WIPP Site 1 Air Samples-1992 . . . . . 71

FIGURE B6. Net Alpha and Beta Activity-WIPP Site 2 Air Samples-1992 . . . . . . 72

FIGURE B7. Net Alpha and Beta Activity-WIPP Site 3 Air Samples-1992 . . . . . 73 


\section{ACRONYMS}

\begin{tabular}{ll} 
CAM & Continuous Air Monitor \\
CFR & Code of Federal Regulations \\
CH-TRU & Contact Handled Transuranic \\
Ci & Curies \\
CPM & Counts Per Minute \\
DOE & U. S. Department of Energy \\
EEG & Environmental Evaluation Group \\
EPA & U. S. Environmental Protection Agency \\
FAS & Fixed Air Sampler \\
FEL & Feet from East Line \\
FNL & Feet from North Line \\
FSL & Feet from South Line \\
FWL & Feet from West Line \\
HEPA & High Efficiency Particulate Air \\
HVAS & High Volume Air Sampler \\
LLD & Lower Limit of Detection \\
LLD & Lower Limit of Detection by Contractor \\
LVAS & Low Volume Air Sampler \\
NESHAP & National Emission Standards for Hazardous Air Pollutants \\
NRC & U. S. Nuclear Regulatory Commission \\
QA & Quality Assurance \\
RH-TRU & Remote Handled Transuranic \\
TRU & Transuranic \\
WID & Waste Isolation Division \\
WIPP & Waste Isolation Pilot Plant \\
\hline
\end{tabular}




\section{EXECUTIVE SUMMARY}

The purpose of the EEG preoperational monitoring program is to document the existing concentrations of selected radionuclides in various environmental media collected from the vicinity of the WIPP site to provide a basis of comparison of any effects of future WIPP operations. The basic methodology for conducting environmental surveillance both on-site and off-site was outlined by Spiegler (1984). This report represents a continuation of the EEG baseline data beginning in 1985, previously reported in EEG-43, EEG-47, EEG-49 and EEG-51. Such radionuclide baseline data are important in order to determine whether future WIPP operations with radioactive waste have affected concentrations of these radionuclides in the environment. EEG data are consistent with similar environmental measurements obtained by DOE beginning in 1985 .

Since late 1985, the EEG has collected or received as split samples 2,443 air filters with particulates, 202 water samples, 16 biota samples and 13 soil/sediment samples. A total of 5,946 specific radionuclide analyses have been performed on these samples.

As reported previously by EEG (EEG-43, EEG-47, EEG-49 and EEG-51), observed concentrations of U-238 daughter radionuclides were not in equilibrium with the parent radionuclide in water samples. This observation is consistent with different radionuclide mobility in the environment. In a notice of proposed rule making for 40 CFR 141 (US EPA 1991), the Environmental Protection Agency (EPA) National Primary Drinking Water Regulations reflect this in the calculated activity-to-mass ratio of $1.3 \mathrm{pCi} / \mu \mathrm{g}$ of uranium using a geometric mean of the U-234:U-238 ratio in water supplies of 2.7. Ra-226 and Ra228 were reported in a number of water samples in concentrations similar to those previously published by EEG and DOE.

In a continuing effort to establish lower limits of detection, EEG provided the contractor laboratory with clean (blank) air filters for radiochemical analysis. Data from these analyses were used to calculate lower limits of detection (LLD) for air samples based upon 
procedure blanks rather than instrument counting blanks. Similar water blanks have also been submitted for analysis but these data are statistically inadequate at this time for use in LLD calculations.

Radionuclide concentrations in soil were also consistent with other data reported by EEG and DOE in the WIPP environment. 


\subsection{INTRODUCTION}

The purpose of the Environmental Evaluation Group's (EEG) monitoring program at the Waste Isolation Pilot Plant (WIPP) is to establish baseline measurements of radionuclide concentrations at the WIPP facility and in the surrounding environment. The EEG surveillance parallels the pre-operational baseline measurements program conducted by the Waste Isolation Division (WID) of Westinghouse Electric Corporation, which is the U. S. Department of Energy's (DOE) prime contractor for WIPP.

The WIPP project is intended to be a repository for the disposal of transuranic (TRU) radioactive waste resulting from the defense activities of the United States. The WIPP mission is to dispose of $176,000 \mathrm{~m}^{3}$ (6.2 million cubic feet) of contact-handled (CH-TRU) waste and $7,080 \mathrm{~m}^{3}$ ( 250,000 cubic feet) of remote-handled (RH-TRU) waste (US DOE, OERWM 1990). The total radioactivity from CH-TRU waste at WIPP will be about $1.01 \mathrm{x}$ $10^{7}$ Curies (Ci) (US DOE, OERWM 1990) and a maximum of $5.1 \times 10^{\circ} \mathrm{Ci}$ from RH-TRU waste (NM and US DOE 1984). Under authorizing legislation (US Congress 1979) Public Law 96-164, the WIPP facility is exempt from U. S. Nuclear Regulatory Commission (NRC) regulations.

The U. S. Environmental Protection Agency (EPA) Standards, 40 CFR Part 191 (US EPA 1990), "Environmental Radiation Protection Standards for Management and Disposal of Spent Nuclear Fuel, High-Level and Transuranic Radioactive Wastes, " were promulgated in November 1985, vacated in 1987 and reissued in 1993 (US EPA 1993). Subpart A of 40 CFR 191 limits the combined annual radiation dose to the public to 25 millirems to the whole body and 75 millirems to any critical organ from waste emplacement and storage operations at DOE disposal facilities which are not regulated by NRC. Subpart B of 40 CFR 191 establishes performance standards for long-term containment and releases of radioactivity to the accessible environment. Subpart B was vacated by the First Circuit Court of Boston in June of 1987 on the grounds that the regulation was less stringent than the requirements of the Clean Water Act of 1971 and failed to follow the Administrative 
Procedures Act. Within days, the State of New Mexico and DOE signed an agreement in July 1987 to continue assessment of potential compliance with the vacated standard until new standards were promulgated (which occurred in December of 1993). While WIPP is in the research and development phase, 40 CFR 61 (NESHAP) limits the effective dose to 10 mrem from WIPP airborne emissions.

The Environmental Evaluation Group established a preoperational environmental monitoring program in 1984 under terms of the July 1981 Consultation and Cooperation (C \& C) Agreement and the December 1982 Supplemental Stipulated Agreement. The National Defense Authorization Act for Fiscal Year 1994, Public Law 103-160 (US Congress 1993) authorized continued funding of the EEG's environmental monitoring program. Data contained in this report are a continuation of the preoperational monitoring baseline studies outlined in Spiegler (1984) and reported in Kenney et al. (1990), Kenney and Ballard (1990), Kenney (1991) and Kenney (1992). EEG plans to continue pre-operational environmental monitoring until waste starts arriving at WIPP and will continue the monitoring program during the operational phase.

\subsection{ENVIRONMENTAL SETTING OF THE WIPP SITE}

The WIPP facility is located in Eddy County in southeastern New Mexico, approximately $42 \mathrm{~km}$ (26 mi) east of Carisbad (Figure 1). The facility is located on a sandy plain at an elevation of $1,040 \mathrm{~m}(3,410 \mathrm{ft})$ above sea level. Prominent natural features near the facility include Livingston Ridge and Nash Draw, about $8 \mathrm{~km}(5 \mathrm{mi})$ west of the facility. Nash Draw is a shallow, dog-bone shaped drainage course between $8 \mathrm{~km}(5 \mathrm{mi})$ and $18 \mathrm{~km}$ (11 mi) in width, characterized by surface impoundments of brine water (Figure 2). Livingston Ridge is a bluff that marks the eastern edges of Nash Draw. Other prominent features of the region include the Pecos River, located about $22 \mathrm{~km}(14 \mathrm{mi})$ west of the facility, and the Carlsbad Caverns National Park about $68 \mathrm{~km}(42 \mathrm{mi})$ west-southwest of the WIPP facility. 


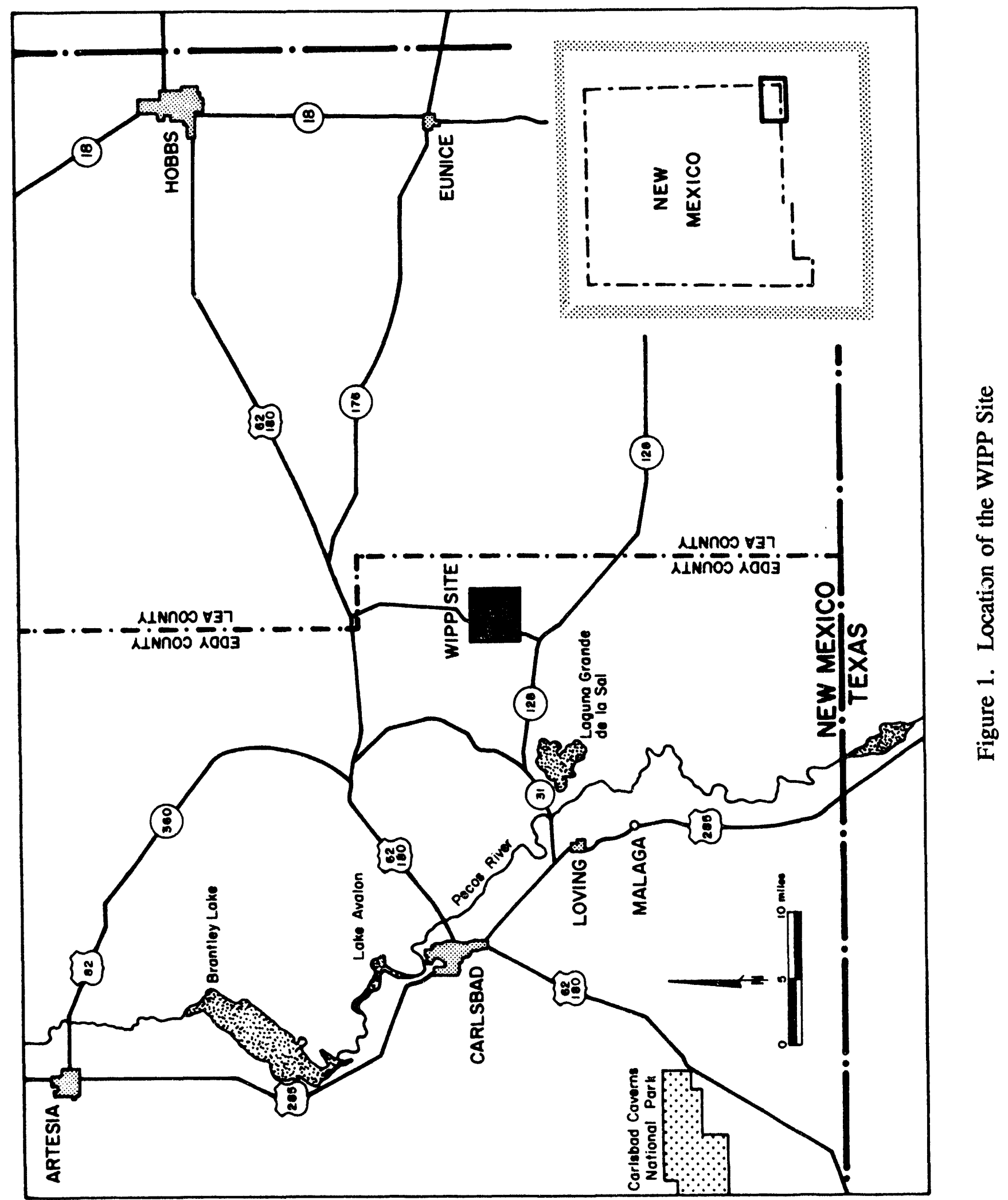




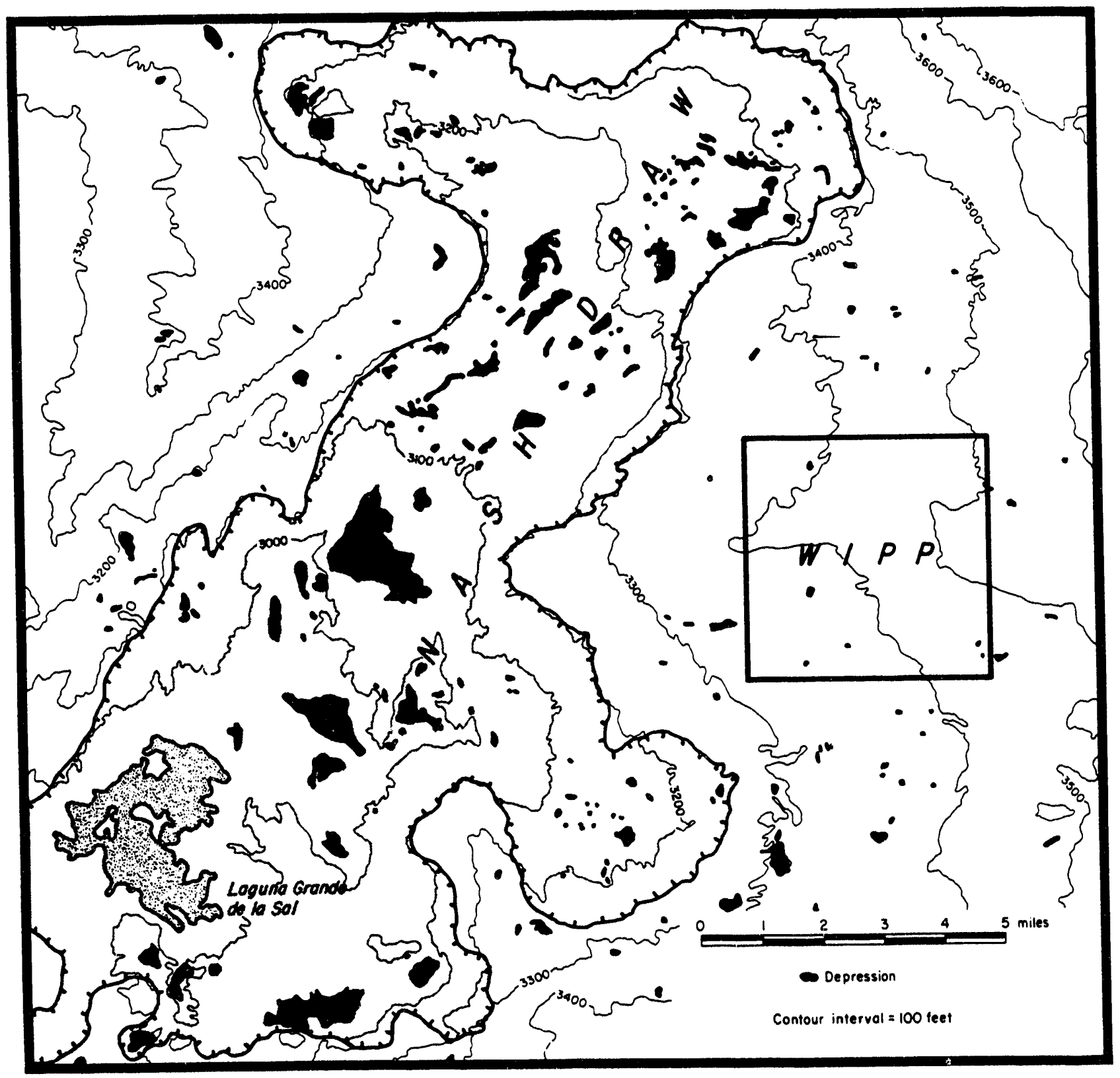

Figure 2. Nash Draw and Depressions Near the WIPP Site, Based on USGS Nash Draw Quadrangle, 15 Minute Series 
Chaturvedi and Channell (1985) suggest that the two major discharge points for waters from the Rustler Formation are into the Pecos River in an area known as Malaga Bend and into Laguna Grande de la Sal. The Laguna Grande de la Sal receives flow from several springs along the margin of the lake. Potentiometric contours for various zones within the Rustler point to the Laguna Grande de la Sal as a secondary discharge point for the Rustler waters. Because the Rustler Formation lies directly above the Salado Formation which contains the WIPP repository, EEG includes water samples from the discharge of the Rustler Formation areas in the radionuclide baseline program.

The nearest population centers include the village of Loving (population 1,500), located 29 $\mathrm{km}(18 \mathrm{mi})$ southwest of the facility, and the city of Carlsbad (population 28,400), located $42 \mathrm{~km}(26 \mathrm{mi})$ west of the facility. Other towns within an $80 \mathrm{~km}(50 \mathrm{mi})$ radius include Artesia, Eunice, Hobbs, Jal, and Lovington.

The climate in the region of the facility is semi-arid with an average annual precipitation in Carlsbad of $207.76 \mathrm{~mm}$ (10.66 in) between 1951 and 1980 (US DOC 1992). During 1992 a total of $382.42 \mathrm{~mm}$ (12.93 in) of precipitation was received at the WIPP site (US DOC 1992). Much of the precipitation falls during intense thunderstorms in the spring and summer. Winds are generally from the southeast toward the northwest (US DOE, WIPP 1991).

Surface structures of the facility are located in sections 20 and 21 of township 22 south, range 21 east, N.M.P.M., in Eddy County, New Mexico. The surface areas around WIPP are divided into several zones (US DOE, OERWM 1990) as indicated in Figure 3. Zone I, lorated in sections 20 and 21 of township 22 south, range 31 east, has an area of 14 ha (35 acres) and contains most of the surface structures associated with WIPP. It is enclosed by chain link fence and patrolled by security guards to maintain restricted access. The secured area boundary surrounds Zone I and is marked with a barbed wire fence. Zone II is the next larger subdivision of the facility although there are no surface markers to identify this zone. Zone II is 728 ha (1,800 acres) in size and represents the maximum extent of the area available for underground development. The WIPP outermost facility boundary, which 
R3 1E

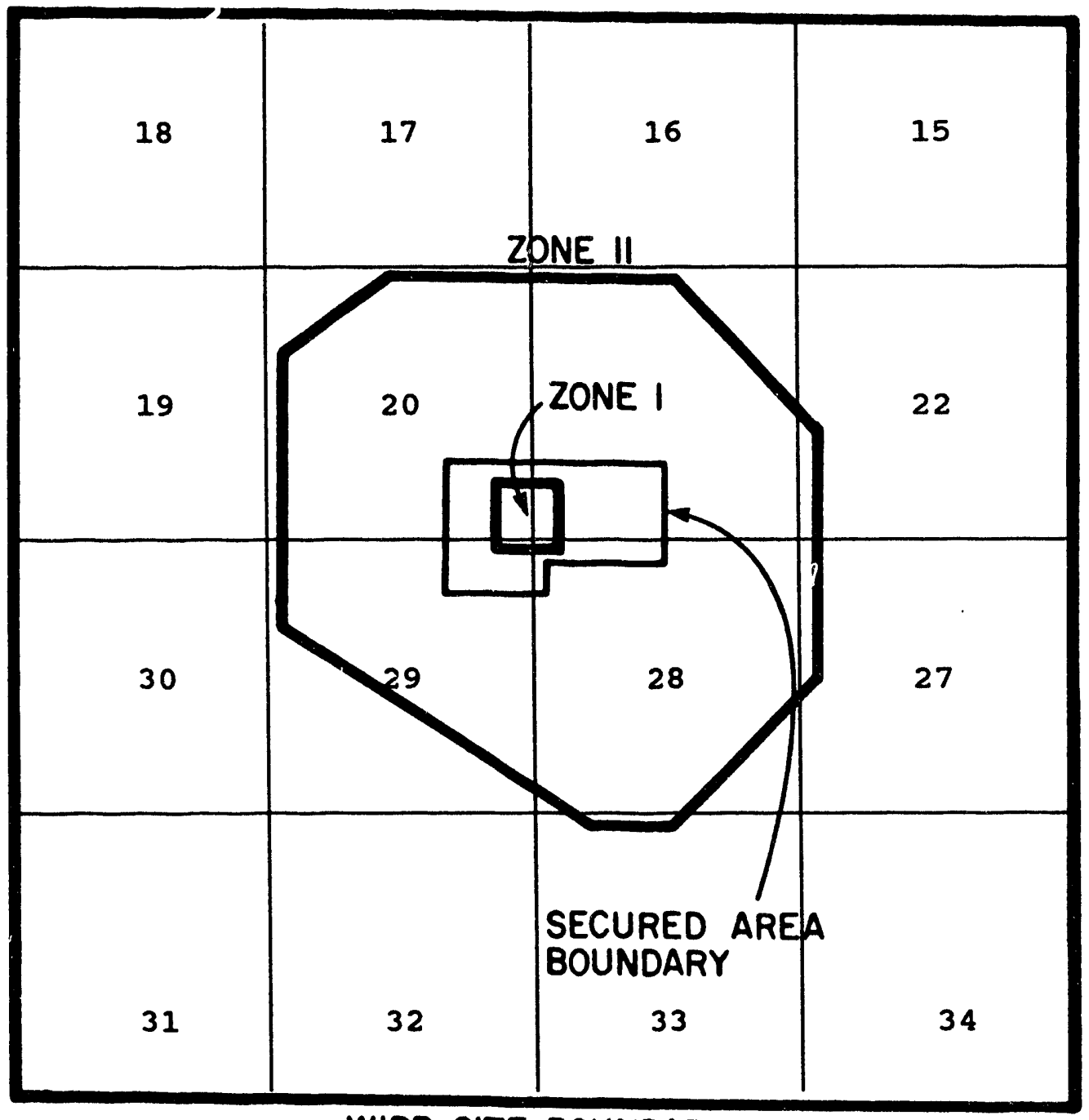

T22S

WIPP SITE BOUNDARY

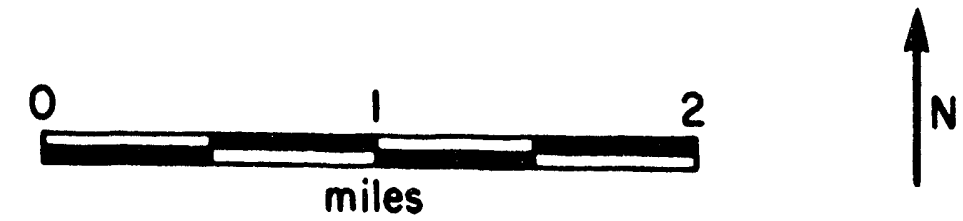

Figure 3. Zones at the WIPP Site 
encompasses 16 square miles, provides a one mile buffer area around Zone II and contains 4,144 ha $(10,240$ acres or 16 sections) and is known as the WIPP site.

Three ranches (Mills, Smith, and Mobley) have property in the vicinity of the WIPP

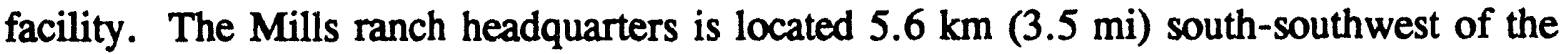
facility center, the Smith headquarters is $8.8 \mathrm{~km}(5.5 \mathrm{mi})$ west-northwest of the facility, and the Mobley ranch is $9.6 \mathrm{~km}(6 \mathrm{mi})$ southwest of the facility. The Mills ranch uses water from "house" and "barn" wells for stock and domestic uses. Water is provided to the Smith ranch from pipelines used by IMC Fertilizer, Inc. and New Mexico Potash Corporation. These pipelines draw from wells completed in the Capitan Reef Formation and the Ogallala Formation, respectively. Mobley ranch uses water hauled from various public water supply systems for domestic use while stock water is obtained from "Mobley Well, " located near the ranch headquarters about $10 \mathrm{~km} \mathrm{(6} \mathrm{mi)} \mathrm{from} \mathrm{the} \mathrm{facility.} \mathrm{All}$ ranch is in the area of WIPP use rain catchment ponds for stock water in addition to water produced from wells.

DOE has purchased all potash leases within the 16 sections comprising the WIPP facility. However, there are two active oil and gas leases in the southwest corner of the WIPP site, one in the north-half of section 31 and one in the south-half of section 31, T-22-S, R-31-E (Silva and Channell 1992). These two oil and gas leases are at depths greater than 6,000 feet and are part of the James Ranch Unit currently operated by Bass Enterprises. In 1982, Bass Enterprises drilled a wildcat well just south of the WIPP site, on section 6, township 23 south, range 31 north, with intent to deviate north into section 31 . That well was completed to a depth of 4,596 meters $(15,078 \mathrm{ft})$ into the Atoka Formation under section 31. The impact of drilling additional wells into this lease and the continued production of gas from the existing well are not yet known.

Although there are no dairies within 40 miles of the WIPP facility, a large amount of alfalfa is grown in the Pecos Valley between Roswell and Malaga, New Mexico. The alfalfa crop is used in cattle feeding operations mainly in New Mexico and Texas. Cotton and pecans are the other major crops grown in the Pecos Valley. 
Geologically, the WIPP repository horizon is situated at a depth of $655 \mathrm{~m}(2,150 \mathrm{ft})$ below land surface in the Permian Age Salado Formation (Figure 4). The Salado is a $610 \mathrm{~m}$ $(2,000 \mathrm{ft})$ thick bedded-salt formation overlain by the Rustler Formation. The Rustler Formation consists of anhydrite and siltstone beds and contains two water-bearing zones, the magenta and culebra dolomites, at $170 \mathrm{~m}(568 \mathrm{ft})$ and $205 \mathrm{~m}(672 \mathrm{ft})$ below land

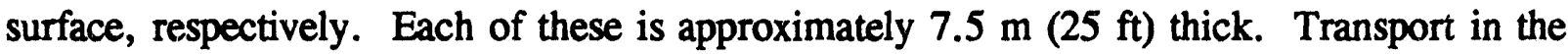
water-bearing units of the Rustler Formation represents the main potential hydrologic pathway to the biosphere from the repository. The culebra dolomite is considered to be the most important hydrologic pathway for release calculations because it is the most transmissive unit in the area. A recent interpretation (Sandia National Labs 1989) of the culebra freshwater-head data indicates a southerly flow across the WIPP site with southwesterly flow occurring south of the site. Radiological baseline data for the culebra and the less productive magenta dolomite are being collected because of their importance to long-term release scenarios.

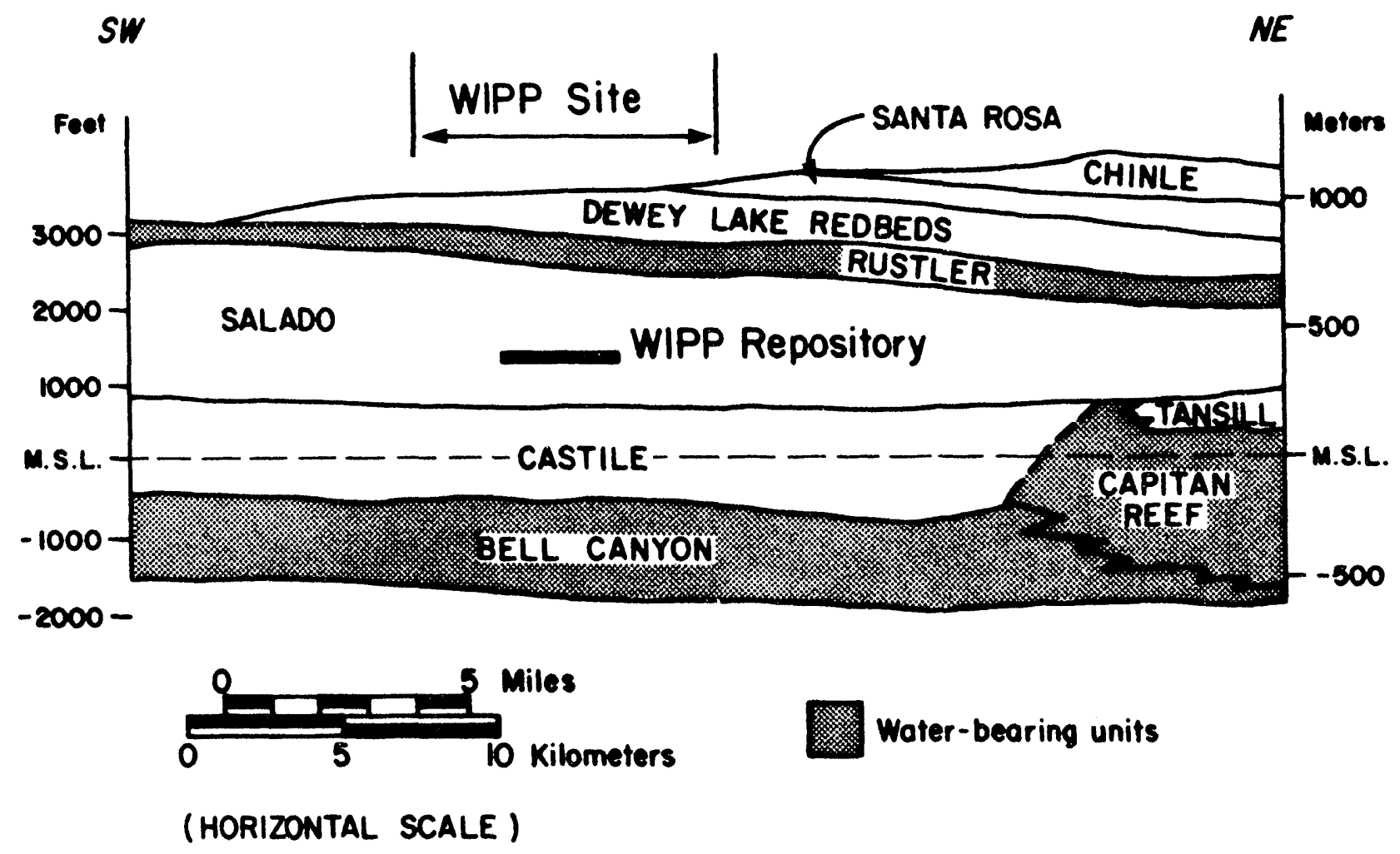

Figure 4. Stratigraphy at the WIPP Site 


\subsection{SUMMARY OF THE PREOPERATIONAL PROGRAM}

The EEG implemented a preoperational environmental surveillance plan (Spiegler 1984) to establish baseline data on potential exposure pathways as summarized in Table i. A high priority continues to be assigned to air sampling and analysis because of the potential for accidents which could result in an airborne releaze. The air sampling system deployed by EEG provides the potential for early detection of releases and subsequent atmospheric dispersion. The preoperational environmental surveillance program includes sampling of other environmental pathways such as groundwater, surface water, public drinking water, biota, soil, and sediment. Radiochemical analyses of environmental samples are performed for the long-lived radionuclides Pu-238, Pu-239+240, Am-241 (plus the naturally-occurring radionuclides $\mathrm{U}, \mathrm{Th}, \mathrm{Ra}$ ) and long-lived fission products, such as Cs-137 and $\mathrm{Sr}-90$, which are found in the WIPP waste.

\subsection{Air Surveillance}

The exhaust air effluent from the underground mine is not continuously filtered because of the large air flow rate required for mine safety. Provisions have been made to filter exhaust air through the high efficiency particulate air (HEPA) filters should a release be detected. The pressure drop across the HEPA filters is large and would result in much lower exhaust air flow rates. Hence, there is the potential for chronic, unfiltered, low-level releases of TRU contaminants during the emplacement, test or retrieval process. In the event of an accident, acute releases could occur prior to the shift of exhaust air through the HEPA filters.

The fixed air sampler (FAS) at stations A and B sample at a flow rate of $0.94 \mathrm{~L} / \mathrm{s}$ (2 $\mathrm{ft}^{3} / \mathrm{min}$ ). Filters are changed following approximately 24 hours of sampling which produces a nominal sample volume of $81.6 \mathrm{~m}^{3}\left(2,880 \mathrm{ft}^{3}\right)$. Filters are not normally changed on weekends and holidays due to the low dust loading. Quarterly composites of FAS filters collected from stations A and B each contain an air sample volume of approximately 


\begin{tabular}{|c|c|c|c|}
\hline $\begin{array}{l}\text { ENVIRONMENTAL } \\
\text { MEDIUN }\end{array}$ & LOCATION & $\begin{array}{l}\text { SAMPLING/AMALYYSIS } \\
\text { FREQUENCY }\end{array}$ & PARAMETER \\
\hline Air & $\begin{array}{l}4 \text { Off-site and } 3 \text { on-site } \\
\text { Low Volume Air Sampler } \\
\text { Locations }\end{array}$ & $\begin{array}{l}\text { Cont inuously/ } \\
\text { Quarterly Composite }\end{array}$ & $\begin{array}{l}\text { gross alpha, gross beta, Pu-238, } \\
\text { Pu-239+240, Am-241, Cs-137, Sr-90, } \\
\text { Th-228, Th-230, Th-232, Ra-226, Ra-228 }\end{array}$ \\
\hline Surface Water & $\begin{array}{l}\text { Pecos River } 2 \text { Locations } \\
\text { Laguna Grande de La Sal } \\
\text { Surface Stock Tanks } \\
5 \text { Locations }\end{array}$ & Annual ly/Annually & $\begin{array}{l}\text { gross alpha, gross beta, Pu-238, } \\
\text { Pu-239+240, Am-241, Tritium, Cs-137, } \\
\text { Sr-90, Ra-226, Ra-228, U-233+234, } \\
U-235, U-238, T h-228, T h-230, T h-232\end{array}$ \\
\hline Groundwater & 22 Wells & Annual ly/Annual ly & $\begin{array}{l}\text { gross alpha, gross beta, Pu-238, } \\
\text { Pu-239+240, Am-241, Tritium, Cs-137, } \\
\text { Sr-90, Ra-226, Ra-228, U-233+234, } \\
\text { U-235, U-238, Th-228, Th-230, Th-232 }\end{array}$ \\
\hline $\begin{array}{l}\text { Municipal } \\
\text { Drinking Water }\end{array}$ & 4 Systems & Annual ly/Annual ly & $\begin{array}{l}\text { gross alpha, gross beta, Pu-238, } \\
\text { Pu-239+240, Am-241, Tritium, Cs-137, } \\
\text { Sr-90, Ra-226, Ra-228, U-233+234, } \\
U-235, U-238, \text { Th-228, Th-230, Th-232 }\end{array}$ \\
\hline $\begin{array}{l}\text { Soil and } \\
\text { Sediment }\end{array}$ & 3 sites & Annual ly/Annual ly & $\begin{array}{l}\text { gross alpha, gross beta, Pu-238, } \\
\text { Pu-239+240, Cs-137, Sr-90, U-233+234, } \\
\text { U-235, U-238, Th-228, Th-230, Th-232 }\end{array}$ \\
\hline Biota & 2 Specimens* & Annual ly/Annually & $\begin{array}{l}\text { Pu-238, Pu-239+240, An-241, Tritium, } \\
\text { Cs-137 }\end{array}$ \\
\hline \multicolumn{4}{|l|}{$\begin{array}{l}\text { Facility } \\
\text { Effluents }\end{array}$} \\
\hline Air & $\begin{array}{l}2 \text { Underground } \\
\text { Ventilation Exhaust } \\
\text { (Stations } A \& B \text { ) }\end{array}$ & $\begin{array}{l}\text { Continuouslyl } \\
\text { Quarterly Composite }\end{array}$ & $\begin{array}{l}\text { gross alpha, gross beta, Pu-238, } \\
\text { Pu-239+240, Am-241, Cs-137, Sr-90, } \\
\text { Th-232, Th-230, Th-228, Ra-226, Ra-228 }\end{array}$ \\
\hline Sewage & 1 Lagoon & Semi annually & $\begin{array}{l}\text { gross alpha, gross beta, Pu-238, } \\
\text { Pu-239+240, Am-241, Tritium, Cs-137, } \\
\text { Sr-90, Ra-226, Ra-228, U-233+234, } \\
U-235, U-238, T h-228, \text { Th-230, Th-232 }\end{array}$ \\
\hline $\begin{array}{l}\text { Storm Water } \\
\text { Runoff }\end{array}$ & WIPP Zone I & Annually & $\begin{array}{l}\text { gross alpha, gross beta, Pu-238, } \\
\text { Pu-239+240, Am-241, Tritium, Cs-137, } \\
\text { Sr-90, Ra-226, Ra-228, U-233+234, } \\
U-235, U-238, \text { Th-228, Th-230, Th-232 }\end{array}$ \\
\hline
\end{tabular}

*Sampling performed by DOE 
$7,344 \mathrm{~m}^{3}\left(259,200 \mathrm{ft}^{3}\right)$. A tamper evident seal is installed on the FAS with each new filter and a strip chart showing the air flow through the system during the sampling period is collected with each loaded filter. Flow is regulated through each FAS through use of an anemometer and flow controller. EEG staff are present for each filter exchange, data and air flow strip chart collection.

To detect acute releases, the first level of air sampling (excluding the effluent air sampling to be done in the exhaust ducts at Stations A and B) occurs inside of Zone I of the facility in the predominant downwind direction. Air samples are collected using continuously operated low volume air samplers (iVAS) which collect air particulates on $102 \mathrm{~mm} \mathrm{(4} \mathrm{in)}$ diameter borosilicate microfiber filters at a rate of $2.34 \mathrm{~L} / \mathrm{s}\left(5 \mathrm{ft}^{3} / \mathrm{min}\right)$. A typical sampling period lasts for seven days which provides a sample volume of approximately $1.4 \times 10^{6}$ liters $\left(5 \times 10^{4} \mathrm{ft}^{3}\right)$. The actual sample volume is used in the calculation to determine radionuclide activity concentration, lower limit of detection (LLD), and analytical error.

The air sample filter is located at a distance equal to or greater than the height of the instrument housing in an upward facing, non-directional configuration. The filter is protected from rain and snow degradation through the use of a rain shield described by Liu and Pui (1980). Wind tunnel test performed at the University of Minnesota with sampling devices using the rain shield design indicate high aspiration efficiency with little dependence on wind speed (Liu and Pui 1980).

Air sampling is accomplished by strategic placement of low volume air samplers within WIPP Zones I and II (Figure 5). The LVAS designated as Site-1 is located approximately $225 \mathrm{~m}$ (740 ft) northwest of the underground exhaust stack within the Zone I boundary.

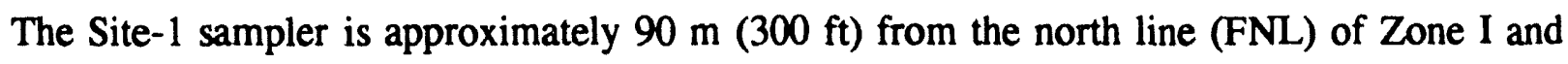
$150 \mathrm{~m}$ (500 ft) from the east line (FEL) of Zone I. The LVAS designated as Site-2 is located approximately $500 \mathrm{~m}(1,600 \mathrm{ft})$ northeast of the WIPP exhaust shaft and unit Site-3 is located approximately $1,000 \mathrm{~m}(3,300 \mathrm{ft})$ northwest of the WIPP exhaust shaft (Figure 6). 


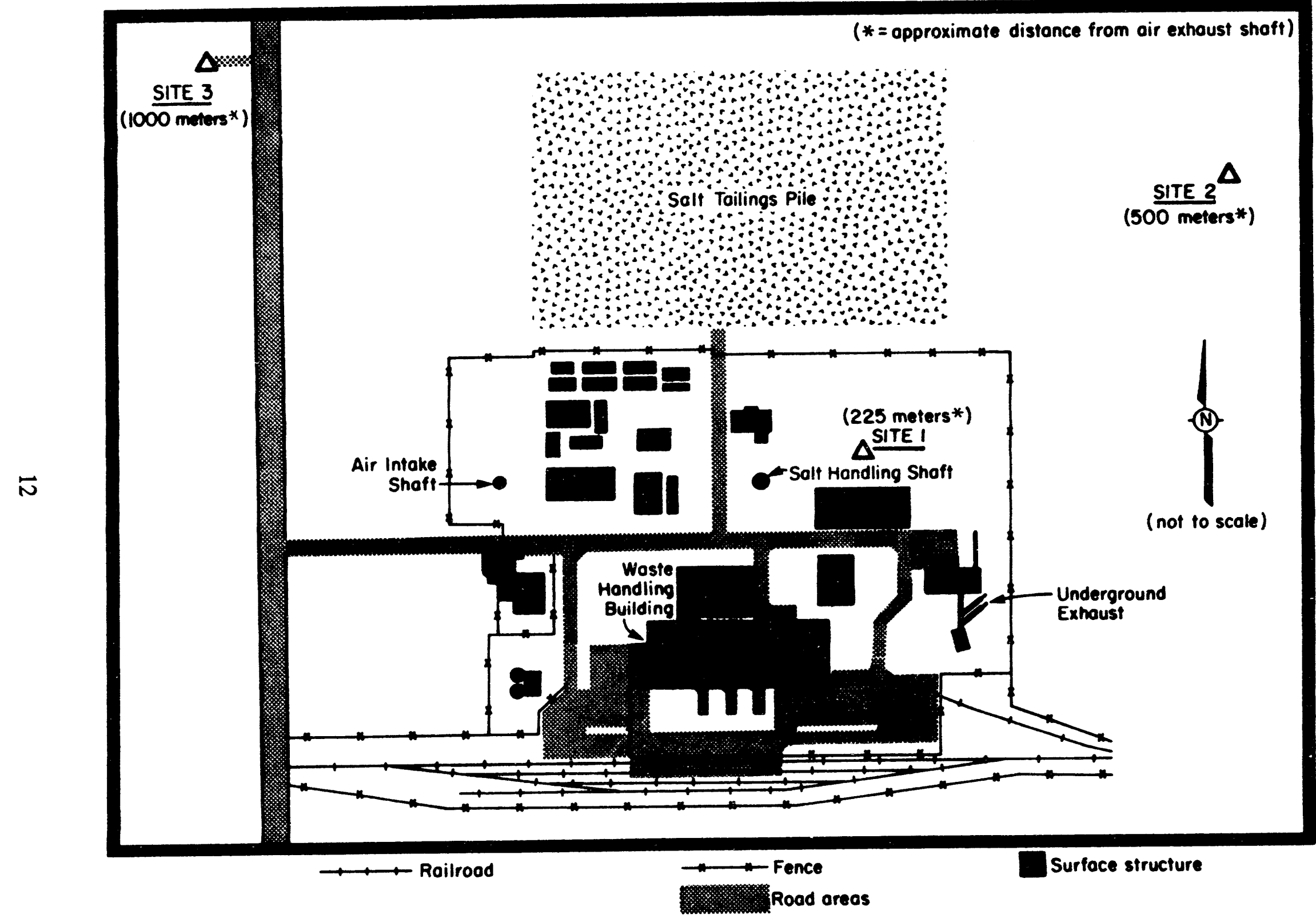

Figure 5. Air Sampling Locations 


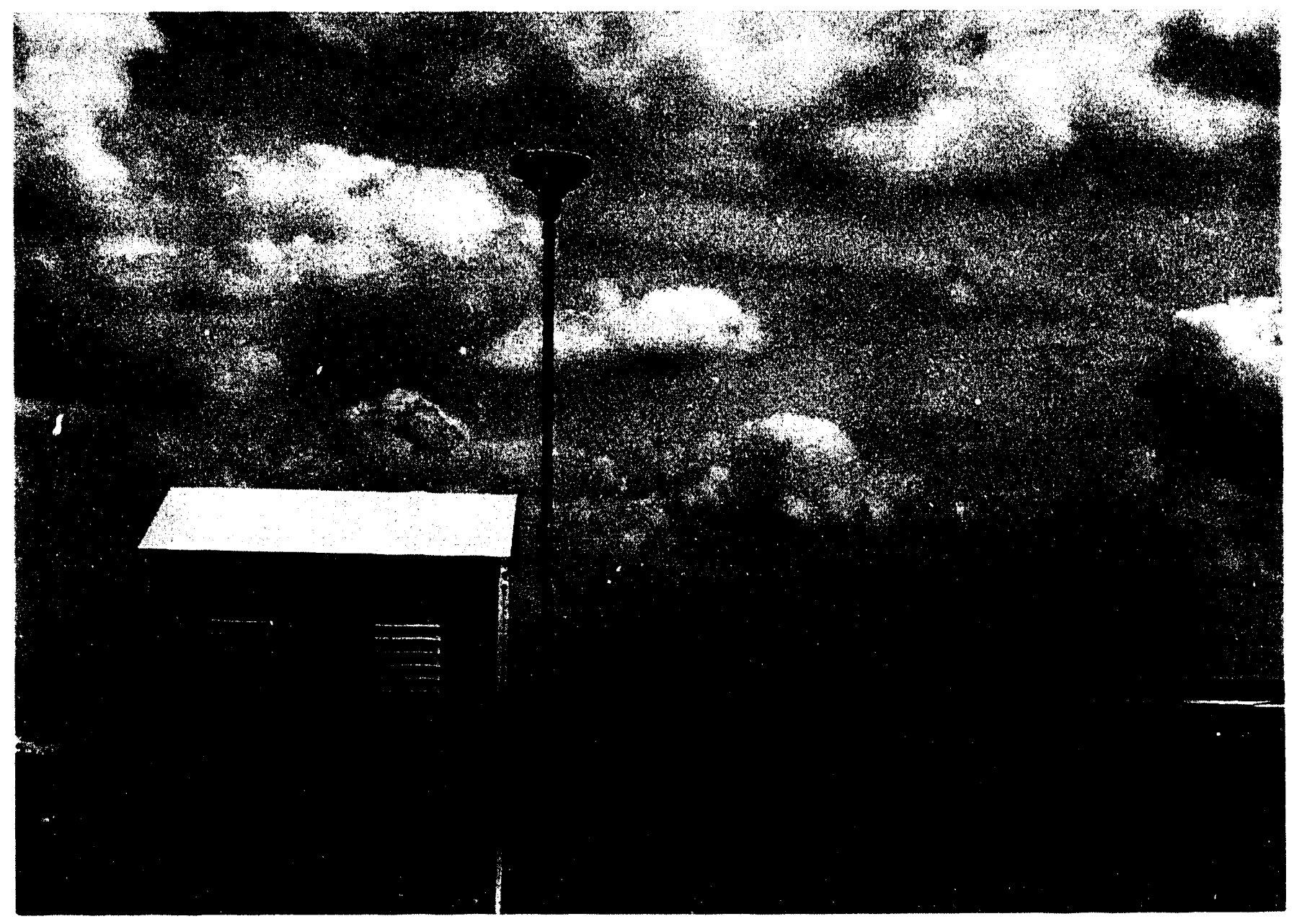

Figure 6. Typical WIPP Site Low Volume Air Sampling Station (S-3) 


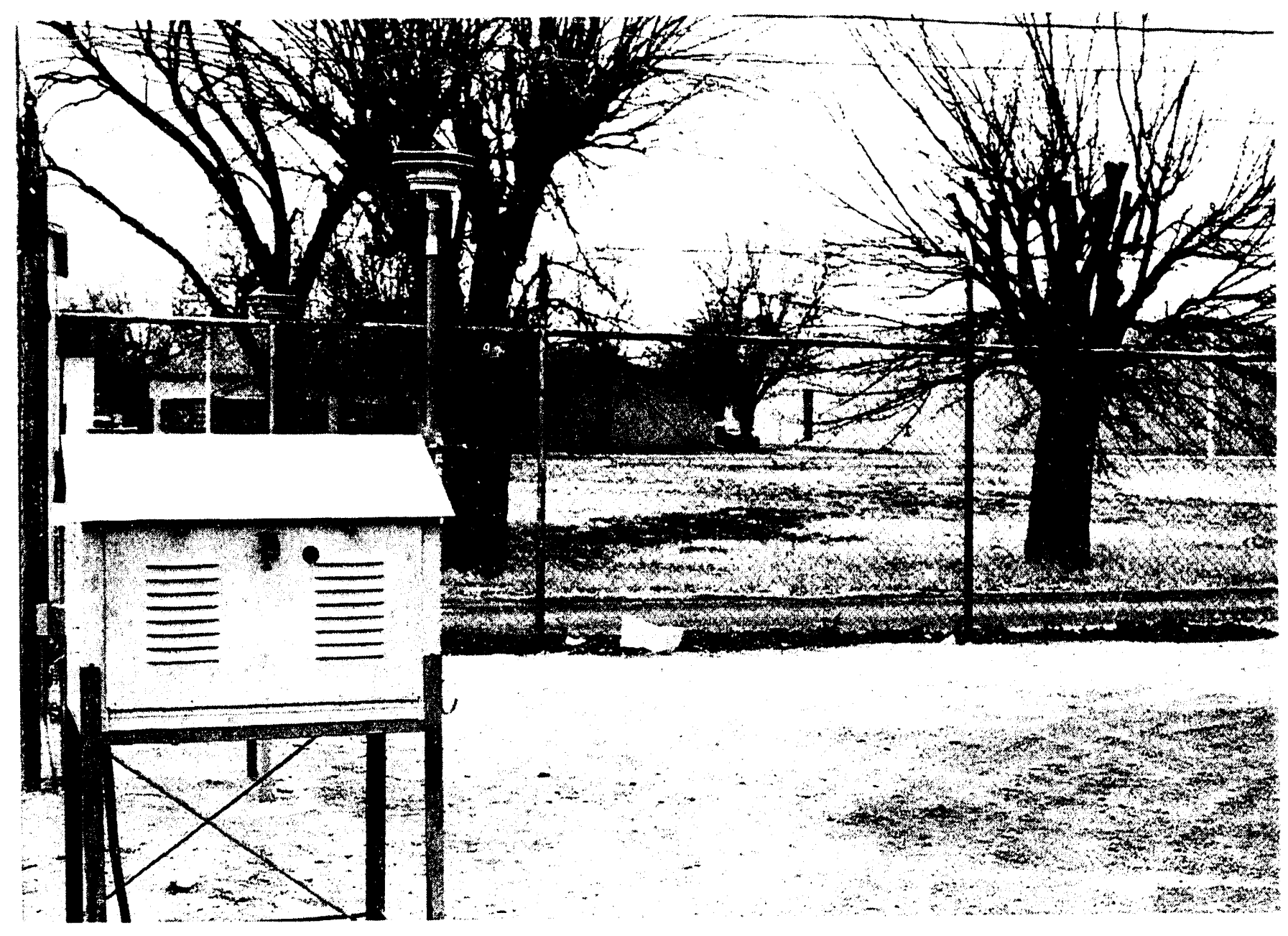

Figure 7. Typical Community Low Volume Air Sampling Station (Carlsbad) 
Low volume air samplers are also continuously operated in Artesia, Carlsbad, Hobbs, and Loving, New Mexico. A typical LVAS station is shown in Figure 7. The LVAS in Artesia is located near the west end of Jaycee Park near the intersection of 26th and Dr. R. W. Harper Drive (township 22S, range 25E, section 24). The Carlsbad LVAS is located at 505 N. Main Street (township 22S, range 27E, section 6). The Loving LVAS is located near the intersection of 5th Street and Elm Street at the Loving Fire Station (township 23S, range 28E, section 21). The LVAS in Hobbs is located near the intersection of Dalmont Street and Snyder Street (township 18S, range 38E, section 34).

It should be noted that from 1985 until January 1, 1990, high volume air samplers (HVAS) were used in the air sampling program in these communities for 24 hours every sixth day. As the expecied time of TRU waste receipt approached, the HVAS which were operated intermittently were replaced with continuously operated LVAS systems in each community. The change in sampling hardware provides for continuous air sampling in the population centers near the WIPP facility.

\subsection{Wate Surveillance}

Groundwater samples are collected from water-bearing zones of the Santa Rosa, Dewey Lake Redbeds, culebra dolomite member of the Rustler, magenta dolomite member of the Rustler, Bell Canyon, and Capitan Reef Formations. Water samples from 12 wells listed on Table 2 are collected by DOE and immediately provided to EEG as splits from their sample. The 12 observation wells are located at the eight locations shown on Figure 8. The samples accepted by EEG are sent to a contract laboratory for radiochemical analysis. Due to budget limitations not all samples are accepted and analyzed by EEG. The locition and formation sampled is indicated for each well in Table 2. Surface water samples are collected by EEG staff.

In all cases, the aliquot designated for radiochemical analysis is preserved with nitric acid to reduce the $\mathrm{pH}$ to less than 2.0. Samples designated for tritium determination are collected in $240 \mathrm{~mL}$ glass containers with conical-shaped polyethylene caps to prevent 


\begin{tabular}{|c|c|c|c|c|c|}
\hline WELL I.D. & TOWNSHIP & RANGE & SECTION & $\begin{array}{l}\text { DISTANCE FROM } \\
\text { SECTION LINE (FT) }\end{array}$ & $\begin{array}{l}\text { FORMATION } \\
\text { SAMPLED }\end{array}$ \\
\hline Barn & 235 & 31E & 7 & Not Available & Dewey Lake Recbeds ${ }^{2}$ \\
\hline Clifton & 235 & 32E & 3 & Not Available & Santa Rosa ${ }^{2}$ \\
\hline Comanche & 225 & $32 E$ & 14 & Not Available & Santa Rosa ${ }^{2}$ \\
\hline Engle & 245 & 32E & 4 & $\begin{array}{r}240.00 \mathrm{FSL}^{1} \\
1500.00 \mathrm{FEL}^{1}\end{array}$ & Culebra Dolomite ${ }^{2}$ \\
\hline Fairview & 235 & $32 E$ & 26 & Not Available & Dewey Lake Recbeds ${ }^{2}$ \\
\hline Mobley & 235 & $30 E$ & 31 & Not Available & Culebra Dolomite ${ }^{2}$ \\
\hline Poker & 245 & $30 E$ & 12 & Not Available & Culebra Dolomite \\
\hline Ranch & 235 & $31 E$ & 7 & Not Available & Dewey Lake Recbeds ${ }^{2}$ \\
\hline Twin (Pasture) & 245 & $31 E$ & 17 & Not Available & Dewey Lake Recbeds \\
\hline Unger & 235 & $31 E$ & 17 & Not Available & Dewey Lake Recbeds ${ }^{2}$ \\
\hline$H-2 C$ & 225 & 31 & 29 & $\begin{array}{r}637.15 \mathrm{FNL}^{\prime} \\
1708.62 \mathrm{FUL}^{\prime}\end{array}$ & Not Available \\
\hline$H-3 B 9$ & 225 & $31 E$ & 29 & $\begin{array}{r}2085.31 \mathrm{FSL}^{\prime} \\
138.10 \mathrm{FEL}^{\prime}\end{array}$ & Magenta Dolomite ${ }^{2}$ \\
\hline $\mathrm{H}-3 \mathrm{~B} 3$ & 225 & $31 E$ & 29 & $\begin{array}{r}2022.35 \mathrm{FSL}^{\prime} \\
217.30 \mathrm{FEL}^{1}\end{array}$ & Culebra Dolomite ${ }^{2}$ \\
\hline$H-4 B$ & $23 s$ & 31E & 5 & $\begin{array}{l}498.47 \mathrm{FNL}^{\prime} \\
632.54 \mathrm{FWL}^{\prime}\end{array}$ & Culebra Dolomite ${ }^{2}$ \\
\hline$H-4 C$ & 235 & $31 E$ & 5 & $\begin{array}{l}446.36 \mathrm{FNL}^{\prime} \\
717.89 \mathrm{FWL}^{\prime}\end{array}$ & Magenta \\
\hline$H-5 B$ & 225 & $31 E$ & 15 & $\begin{array}{r}1008.30 \mathrm{FNL}^{\prime} \\
236.22 \mathrm{FEL}^{1}\end{array}$ & Culebra Dolomite ${ }^{3}$ \\
\hline$H-5 C$ & 225 & $31 E$ & 15 & $\begin{array}{r}1005.55 \mathrm{FNL}^{1} \\
134.95 \mathrm{FEL}^{1}\end{array}$ & Magenta Dolomite ${ }^{3}$ \\
\hline$H-68$ & 225 & $31 E$ & 18 & $\begin{array}{l}196.34 \mathrm{FNL}^{1} \\
322.96 \mathrm{FWL}^{1}\end{array}$ & Culebra Dolomite \\
\hline$H-6 C$ & 225 & $31 E$ & 18 & $\begin{array}{l}281.06 \mathrm{FNL}^{\prime} \\
374.47 \mathrm{FHL}^{\prime}\end{array}$ & Magenta ${ }^{2}$ \\
\hline$H-1183$ & 225 & $31 E$ & 33 & $\begin{array}{l}1501.70 \mathrm{FSL}^{1} \\
105.20 \mathrm{FEL}^{1}\end{array}$ & Culebra Dolomite ${ }^{2}$ \\
\hline $\mathrm{H}-14$ & 225 & $31 E$ & 29 & $\begin{array}{l}372.60 \mathrm{FSL}^{1} \\
562.40 \mathrm{FWL}^{1}\end{array}$ & Culebra Dolomite ${ }^{2}$ \\
\hline HIPP-19 & 225 & $31 E$ & 20 & $\begin{array}{r}2286.50 \mathrm{FNL}^{1} \\
12.70 \mathrm{FEL}^{1}\end{array}$ & Culebra Dolomite ${ }^{2}$ \\
\hline
\end{tabular}

1 From Gonzales (1989)

2 From Randall et al. (1988)

3 From Uhland et al. (1987)

4 From Uhland and Randall (1986)
Note:

FNL = feet from north $l$ ine of section

$F E L=$ feet from east line of section

FSL = feet from south line of section

$F W L=$ feet from west line of section 


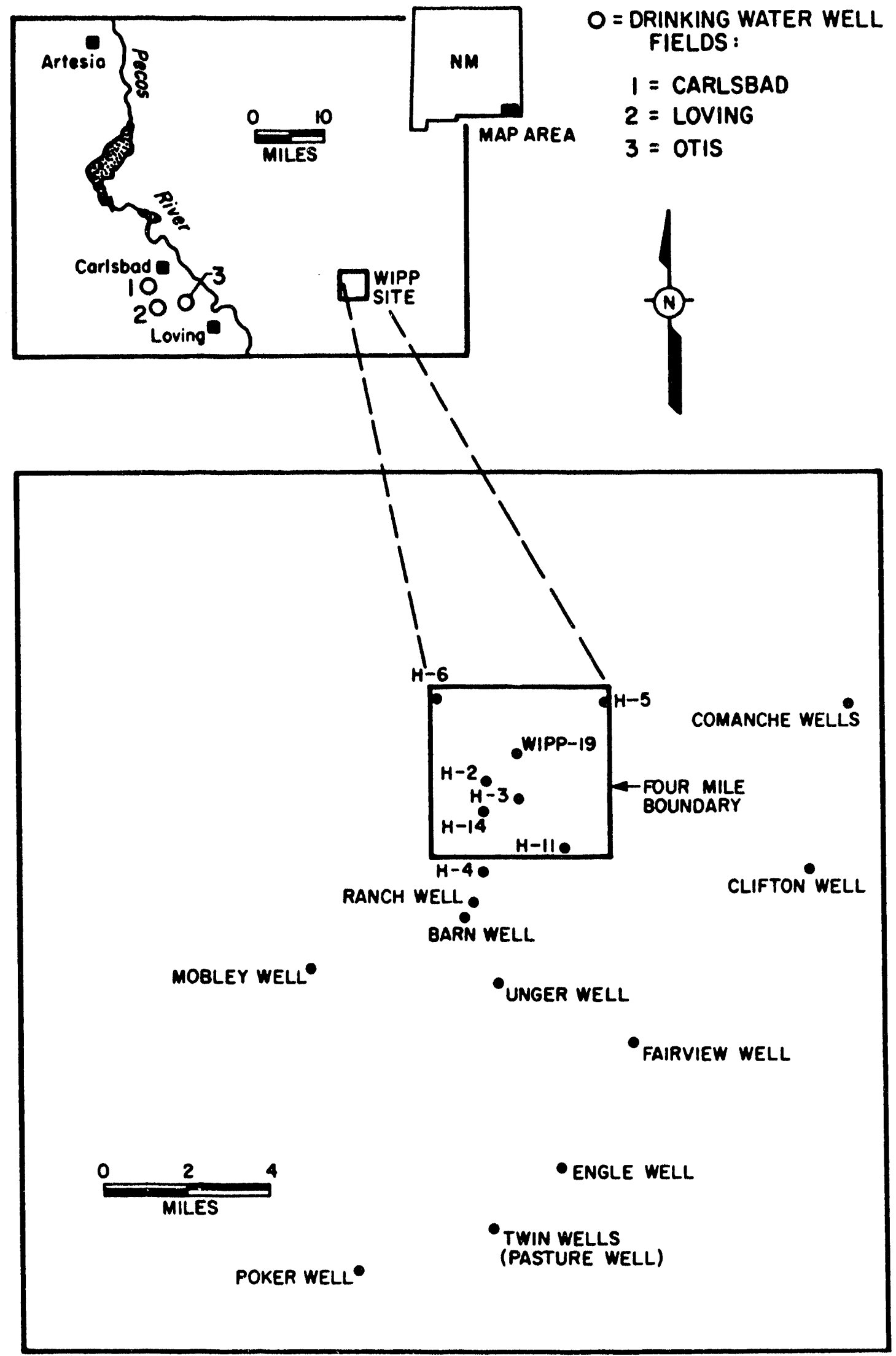

Figure 8. Groundwater Sampling Locations 
ambient air entrapment with the sample. Surface water, groundwater, public drinking water, WIPP wastewater effluent and stormwater effluent samples are sent to a private contractor laboratory for radiochemical analysis. The radiochemical analyses for all water samples are reported in Tables A-9 through A-12 of Appendix A.

An interpretation of the groundwater chemistry data is discussed by Chapman (1988). The major ion data are useful in determining flow paths in the water-bearing units above the level of the WIPP repository. Data on the concentrations and distribution of thorium, radium, and uranium may be used to help predict the mobility of similar radionuclides in the hydrogeochemical setting at WIPP. Flow path and radionuclide mobility information are useful for analyzing release scenarios to assess WIPP's compliance with the long-term disposal requirements contained in EPA regulations (40 CFR Part 191). Radionuclide data collected from groundwater samples could become part of the data base used to evaluate long-term performance of the repository, providing documentation of pre-waste levels for later comparison.

The surface water surveillance program consists of routine sampling of eight bodies of water by EEG staff as shown in Figure 9. Water collected from the Pecos River in Carlsbad provides radionuclide baseline data and a comparison for similar data from the Pierce Canyon area of the Pecos about $19 \mathrm{~km}(12 \mathrm{mi})$ downstream from Carlsbad. Mercer (1983) suggests that saturated zones in the Rustler Formation discharge to the Pecos River near Malaga Bend, about a mile upstream of where the river enters Pierce Canyon. Because of the role of the Rustler Formation as a hydrologic pathway for radionuclide migration, preoperational data from these regions are important. Radionuclide baseline data are collected from surface water in Laguna Grande de la Sal which is located $13 \mathrm{~km}(8 \mathrm{mi})$ southwest of the WIPP facility.

Due to the size of Laguna Grande de la Sal three collection areas are used to form a composite sample. The saline lake is in the storm water drainage from the facility and is a discharge point for shallow groundwater in Nash Draw. Because particulates in air 


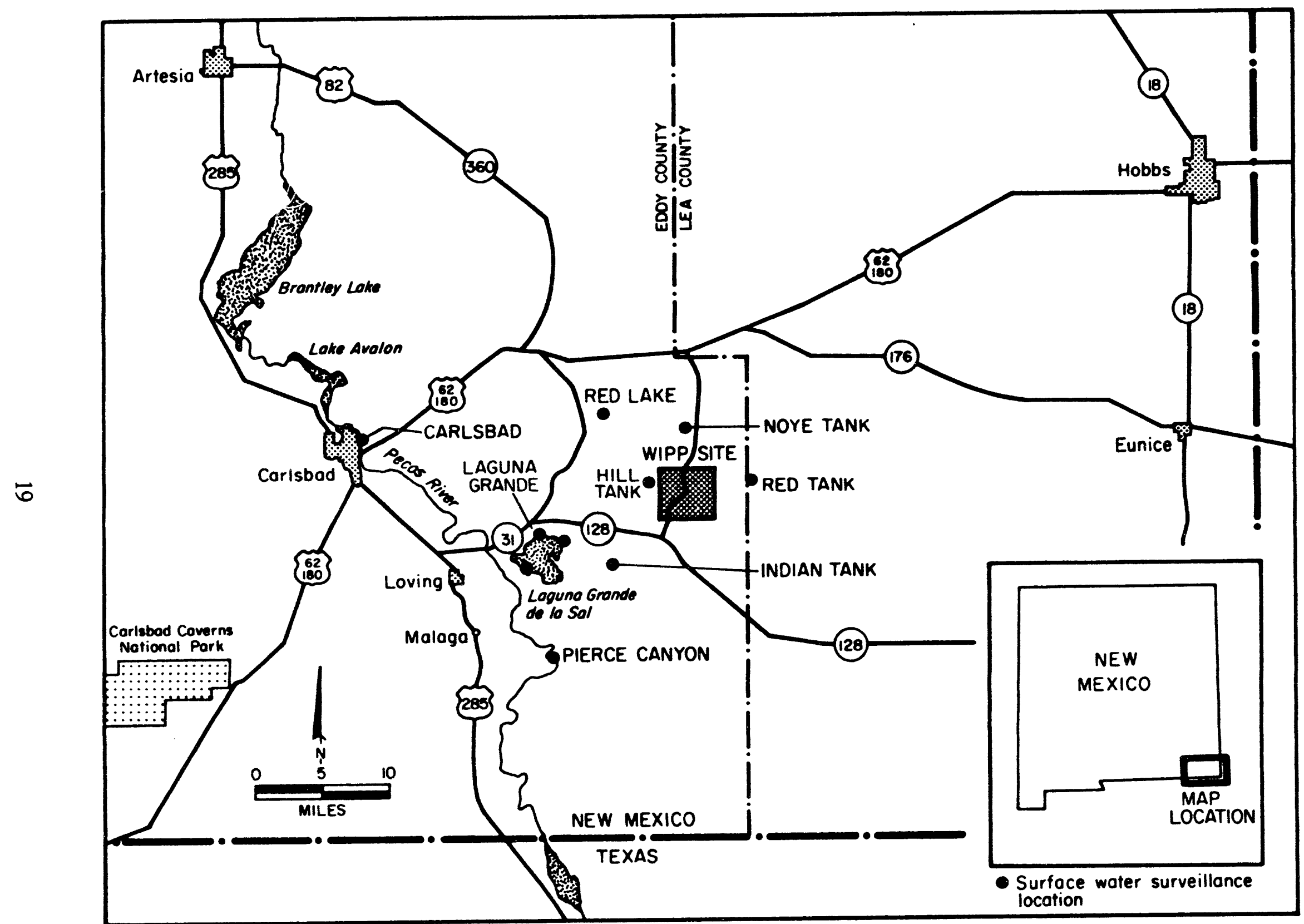

Figure 9. Surface Water Sampling Locations 
emissions from WIPP operations would be expected to fall onto the area watershed, water samples are collected from five nearby rain catchment basins used for livestock and game watering.

Radiochemical data from surface water samples are presented in Table A-10 of Appendix A.

New Mexico Regulations Governing Water Supplies (NM HED 1989) establish a maximum contaminant level (MCL) for $\mathrm{Sr}-90$ at $8 \mathrm{pCi} / \mathrm{L}$, tritium at $20,000 \mathrm{pCi} / \mathrm{L}$, gross alpha at 15 $\mathrm{pCi} / \mathrm{L}$, and $\mathrm{Ra}-226+228$ at $5 \mathrm{pCi} / \mathrm{L}$ in public community water supply systems. EEG collects and analyzes samples from the Carlsbad, Loving/Malaga, Otis, and WIPP water supply systems (Figure 8). Radionuclide data obtained from these public community drinking water systems during this report period did not exceed these MCLs and are presented in Table A-12 of Appendix A.

Mercer (1983) summarized chemical analyses performed by the U. S. Geological Survey on WIPP well samples. Simpson et al. (1985) reported a wide variety of radionuclide analyses of surface and groundwater in the Delaware Basin in an investigation of the mobility of radionuclides in high-chloride environments.

Field and laboratory results from DOE's water quality sampling program are available in Uhland and Randall (1986); Uhland et al. (1987); Randall et al. (1988); US DOE, WIPP (1990); and US DOE, WIPP (1991). Interpretation of data from groundwater in the Culebra Dolomite Member of the Rustler formation is discussed in Chapman (1988) and Ramey (1985).

\subsection{Soil and Sediment Surveillance}

Soil and sediment in the area of WIPP contain a record of deposited radioactive fallout from past atmospheric nuclear weapons testing as well as surface contamination from 
Project Gnome. Cs-137 was one radionuclide identified in the area of the Gnome site during an aerial gamma survey (Berry 1989) which was conducted as a part of WIPP baseline studies. It is believed that a certain amount of this deposited fallout may become resuspended in air particulates under certain atmospheric and soil conditions. Because WIPP TRU waste contain some of the fission products found in fallout, these data are an important component of the environmental baseline data set. In addition, soil samples are routinely available to EEG as split samples from the DOE soil sampling program. Radionuclide data obtained from soil samples collected during this report period are contained in Table A-13 of Appendix A.

\subsection{Biota Surveillance}

Potential ecosystem transport processes at WIPP include the atmospheric dispersion and subsequent contamination of soil, surface water, and vegetation surrounding the WIPP facility. Although inhalation is the predominant exposure pathway to man, ingestion of game, livestock, or fish that had access to the contaminated environment could also provide a pathway for human exposure (US NRC 1983). Due to budget limitations no biota samples were collected during 1992.

Some EEG biotic samples are received as split samples from the DOE environmental program. Biotic samples are sent to a private laboratory for radiochemical analyses as shown in Table 1.

\subsection{WIPP Effluent Surveillance}

The three major effluent streams at the WIPP facility are exhaust air from the underground repository waste area, sewage effluent and stormwater effluent from the Zone I area. Unfiltered air is normally exhausted at approximately $201 \mathrm{~m}^{3} / \mathrm{s}\left(425,000 \mathrm{ft}^{3} / \mathrm{min}\right)$ through an exhaust shaft to the environment. The EEG routinely collects samples from a fixed air sampler which traps particulates from the unfiltered exhaust air at the top of the exhaust 
shaft (Station A) before the air is discharged to the environment (Figure 10). Samples from Stations $\mathrm{A}$ are sent to a private laboratory for radiochemical analysis after initial screening in the EEG laboratory.

Although EEG began collecting filters from these FAS locations in October 1990, the methodology for Station A sample collection was not finalized until October 1991. The analytical radiochemical suite is the same as that indicated for air filters in Table 1. Underground exhaust air will be diverted through high efficiency particulate air filters located on the surface if the continuous air monitor (CAM) in the exhaust shaft on the surface (Station $\mathrm{A}$ ) detects a significant radioactive release. Air passed through the HEPA filters would then be exhausted to the environment at a rate of $28.3 \mathrm{~m}^{3} / \mathrm{s}\left(60,000 \mathrm{ft}^{3} / \mathrm{min}\right)$ through an alternate exhaust duct and sampled at a FAS designated as Station B. Fixed air samples collected from Station B will be analyzed as described above for Station A samples should HEPA filtration be initiated. EEG will not operate a CAM at either Station A or B because it is DOE's responsibility to advise of an alarm or accident situation.

In order to determine the total amount of radioactivity released from the underground at WIPP in the event of an accident, it is necessary to operate FAS units at both Stations A and B during a suspected release (Figure 11). First, contamination could potentially be released to the environment through the unfiltered exhaust stacks beyond Station $A$ before CAM alarms initiate HEPA filtration (Bartlett 1993). Hence, a FAS at Station A is essential. Second, Station B is sampled with a FAS to quantify any releases which might be discharged from the underground to the environment through leakage or failure of the HEPA filtration system and otherwise verify that no further discharge occurred once the bypass valves close. Through analysis of filters from Stations A and B, EEG should have enough data to determine the extent of any significant release through the repository exhaust air.

Air exhausted from the Waste Handling Building will be double HEPA-filtered continuously before discharge to the environment. DOE will maintain CAM systems and FAS systems 


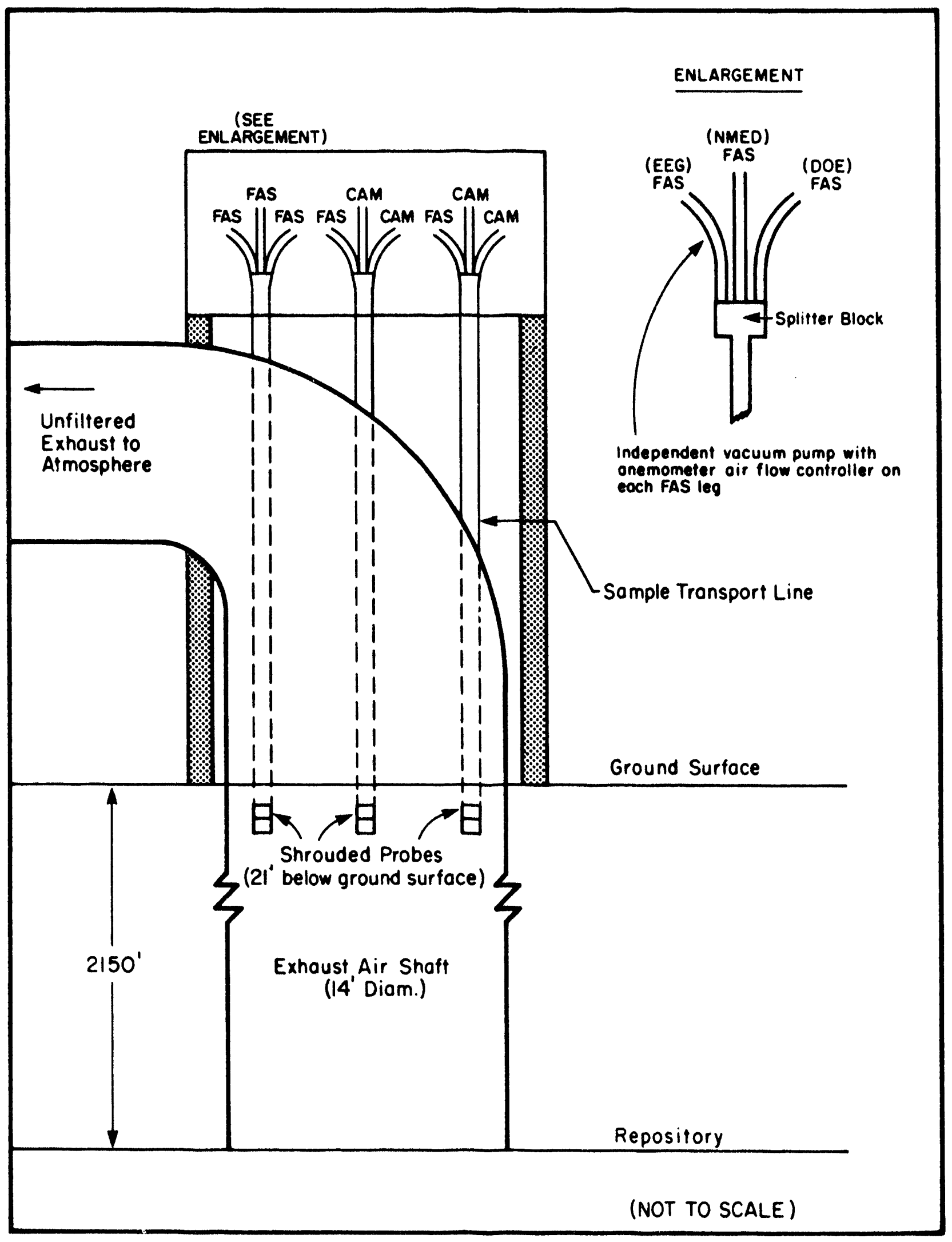

Figure 10. Station A 


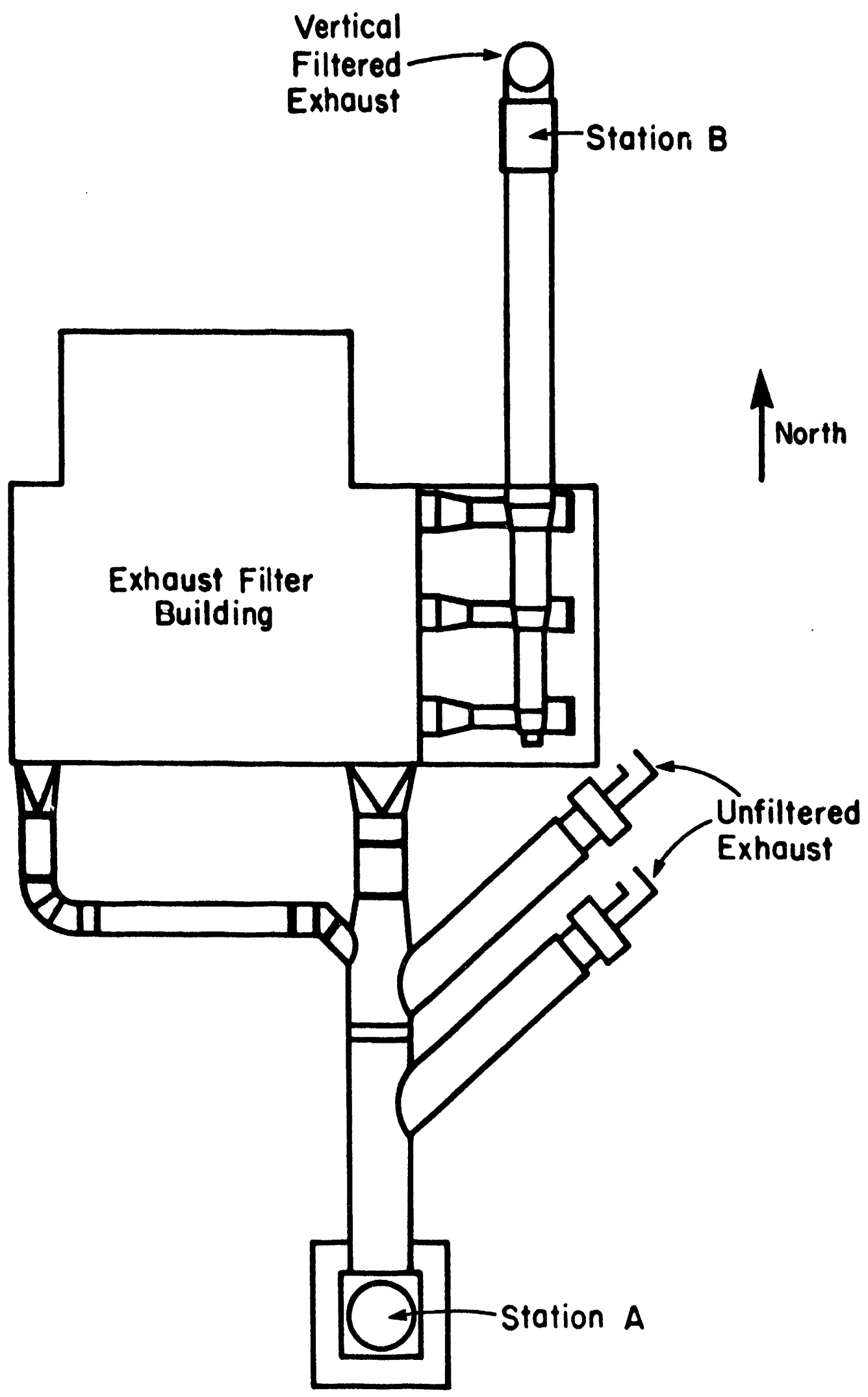

Figure 11. Locations of Station A and B 
in the exhaust duct from this facility at a location designated as Station C. However, due to the low probability of a release through this redundant HEPA-filtered discharge, EEG will not operate a FAS in this exhaust system.

Other effluent streams from the WIPP facility are sewage effluent and storm water runoff from Zone I. The WIPP sewage treatment plant consists of two parallel lined solar evaporation cells followed by two parallel lined polishing cells with final discharge to two lined evaporation cells. Although DOE procedures indicate that potentially contaminated water from waste handling operations will not be introduced into the WIPP sewage system, preoperational monitoring includes sampling of effluent contained in the lined evaporation ponds. Analytical data from radiochemical analyses performed on a primary sewage cell sample are contained in Table A-11 of Appendix A.

\subsection{DISCUSSION OF FINDINGS}

Radiochemical analyses of environmental samples, presented in Appendix A, are required to identify specific radionuclides present in the preoperational WIPP environment. Radiochemical analysis of composite air, water, biota, soil, and sediment samples are performed by an independent commercial laboratory. Gross alpha and gross beta activity levels in samples of water and soil were determined using proportional counting systems. Analyses were preceded by one or more chemical separations.

The equations used by EEG's contractor laboratory in reporting individual radionuclide activity concentrations and counting error at the 95 percent confidence level are presented below. The activity concentration for most radionuclides was calculated by the following equation: 
Radionuclide Activity Conc. = (Net CPM)

(E) (V) (Rc) (Rs) $\left(\mathrm{K}_{1}\right)\left(\mathrm{K}_{2}\right)$

Where:

Radionuclide Activity Conc. $=\mu \mathrm{Ci} / \mathrm{ml}$

Net Counts per minute $(C P M)=$ gross $C P M-$ background $C P M$

$\mathrm{E}=$ Counting efficiency (counts per disintegration)

$\mathrm{V}=$ Sample volume or weight $(\mathrm{ml}$ or $\mathrm{g})$

$R c=$ Fractional chemical yield of carrier

Rs $=$ Fractional average recovery for standards

$\mathrm{K}_{1}=3.7 \times 10^{4}$ disintegrations/second $\mu \mathrm{Ci}$

$\mathrm{K}_{2}=60$ seconds/minute

The 2 sigma analytical error was calculated from the following equation:

$$
\text { Analytical Error }=\frac{1.96\left[S / D_{\bullet}^{2}+B / D_{b}^{2}\right]^{1 / 2}}{(E)(V)\left(R_{c}\right)\left(R_{f}\right)\left(K_{1}\right)\left(K_{2}\right)}
$$

Where:

Analytical Error $=\mu \mathrm{Ci}$ per volume unit (ml or $\mathrm{g}$ )

$1.96=$ Factor to achieve 95 percent confidence level

$\mathrm{S}=$ Sample gross counts (counts)

$B=$ Blank counts (counts)

$D_{\text {. }}$ = Sample counting time (minutes)

$D_{b}=$ Blank counting time (minutes)

$\mathbf{R}_{\mathrm{c}}=$ Fractional chemical yield of carrier

$\mathbf{R}_{\mathbf{q}}=$ Fractional average recovery for standards

$\mathrm{E}=$ Counting efficiency (counts per disintegration)

$\mathrm{V}=$ Volume of sample ( $\mathrm{ml}$ or $\mathrm{g}$ )

$\mathrm{K}_{1}=3.7 \times 10^{4}$ disintegrations $/$ second $-\mu \mathrm{Ci}$

$\mathrm{K}_{2}=60$ seconds/minute 
The EEG contractor laboratory routinely reports a lower limit of detection (LLD $)$ for each analysis based on the results of a periodic determination of the background of the counting instrument but without other factors of the analytical chemical separation process. The contractor laboratory's $L_{L} D_{c}$ can be summarized as follows:

$$
\mathrm{LLD}_{c}=\frac{(4.65)(\mathrm{Sb})}{\left(\mathrm{K}_{1}\right)(\mathrm{E})(\mathrm{V})(\mathrm{Y})(\mathrm{e})^{(-\lambda)(\Delta t)}}
$$

Where:

$4.65=$ Factor to achieve $95 \%$ confidence

$\mathrm{LLD}_{\mathrm{c}}=$ lower limit of detection (microcurie/milliliter) based upon instrument background alone

$S_{\mathrm{b}}=$ standard deviation of instrument bkg (cps)

$\mathrm{E}=$ counting efficiency (cps/dps)

$\mathrm{V}=$ sample volume $(\mathrm{ml})$

$\mathrm{Y}=$ fractional yield of radiochemistry (when applicable)

$\mathrm{K}_{1}=3.7 \times 10^{4}$ disintegrations $/$ second $-\mu \mathrm{Ci}$

$\lambda=$ decay constant $\left(\right.$ seconds $^{-1}$ or years ${ }^{-1}$ )

$\Delta t=$ elapsed time, collection to count (seconds or years)

This formulation of the $\operatorname{LLD}_{\mathrm{c}}$ for a single measurement is intended to follow the guidance of the HASL Procedures Manual (US DOE, EML 1990) and similar sources.

However, a survey of the radiochemical data from environmental samples collected between 1985 and 1988 (Kenney et al. 1990) found that Cs-137 was reported at a concentration of $3.3 \mathrm{E}-9 \mu \mathrm{Ci} / \mathrm{ml}\left(\mathrm{LLD}_{\mathrm{c}}=2.0 \mathrm{E}-9 \mu \mathrm{Ci} / \mathrm{ml}\right)$ in water from the Rustler Formation. The sample in question was collected from an environmental media and under geophysical conditions that would make it highly unlikely that the sample would contain fallout Cs-137 at the concentration reported. It appears that the high Cs-137 concentration was the result of incomplete potassium $(\mathrm{K}-40)$ precipitation followed by a beta count which attributed the 
activity to Cs-137. Radiochemical data collected during 1992 indicated the presence of Pu238 at the $L L D_{c}$ in one water sample and Pu-239+240 at the $L L D_{c}$ in two water samples. Although other environmental monitoring programs have reported similar measurements (Reith et al. 1986, Banz et al. 1987) it is not likely that these analyses represent true detection of environmental levels of fallout radionuclides but are instead a result of inappropriate procedure blanks used to calculate the $L L D_{c}$. These errors might have been reduced through the use of more appropriate procedure blanks.

A detailed analysis of the contractor laboratory log books covering actinide analysis of typical air filter composites revealed the following:

(1) Both EEG procedure blanks and regular sample aliquots are counted for 240 minutes, which results in very few total counts, thus creating the possibility for Poisson errors;

(2) there is significant variability in sample recovery which introduces significant variability in the calibration factor (denominator) of the LLD computation;

(3) instrument backgrounds (the contractor's "blank") are counted significantly longer than the samples themselves ( 2,880 minutes), which violates the assumption (ANSI 1992) that the magnitude of the sample and blank counts are similar; and

(4) the introduction of systematic bias through tracer reagents is not taken into account as a blank systematic error.

If the variance $\left(S_{b}\right)$ is based solely on the observed counts from a detector with the same blank (or no sample blank), then the $S_{b}$ may be underestimated. A better estimate of $S_{b}$ can be made by routine analysis of environmental media devoid of the radioactivity of interest (i.e. uncontaminated air sample filters or water samples). Beginning in the fourth quarter of 1986 , both air filter and water sample blanks were routinely sent to the contract laboratory for analysis along with environmental samples. The resulting blank data were 
used to calculate the LLDs shown in Table 3. The derived variance is more indicative of the total variance of the analytical measurement process. The LLD was calculated using equation (4) below:

$$
\operatorname{LLD}=\frac{4.65 \sigma_{0}}{(\mathrm{~K})(\mathrm{V})}
$$

Where:

$4.65=$ Factor to achieve $95 \%$ confidence

LLD $=$ Lower Limit of Detection $(\mathrm{pCi} / \mathrm{ml})$ as determined using all experimental variations not just the Poisson component

$\sigma_{0}=$ Standard deviation of the contractor reported radionuclide activities from analysis of blank filter composites (pCi/composite)

$\mathrm{K}=$ constant for conversion of $\mathrm{pCi}$ to $\mu \mathrm{Ci}\left(10^{-6} \mu \mathrm{Ci} / \mathrm{pCi}\right)$

$\mathrm{V}=$ volume of air in the composite air sample for which the LLD is reported (ml)

Due to the lack of sufficient data from blank water samples (procedure blanks), LLDs based upon the above equation were not calculated by EEG for water sample data and, therefore, the contractor's $L_{L} D_{c} s$ continue to be reported here.

One important objective of the EEG's preoperational environmental surveillance program is to better understand the radionuclide concentration values and lower limits of detection in environmental samples from the vicinity of the WIPP facility. In a method consistent with the format outlined in NRC Regulatory Guide 4.14 (US NRC 1980), EEG reports all environmental radionuclide concentrations as vaiues, including values less than the lower limit of detection (LLD) or less than zero. 


\begin{tabular}{|c|c|c|c|c|}
\hline RADIONUCLIDE & $\begin{array}{l}\text { No. OF } \\
\text { BLANKS }\end{array}$ & $\begin{array}{c}\text { AVERAGE } \\
\text { CONCENTRATION } \\
\text { (PCi/FILTER CONPOSITE) }\end{array}$ & $\begin{array}{l}\text { STAMDARD } \\
\text { DEVIATIOW }\end{array}$ & $\begin{array}{c}\text { LLD } \\
\text { (PCi/FILTER } \\
\text { CONPOSITE) } \\
\text { AT 95\% CONFIDENCE }\end{array}$ \\
\hline MERICIUN-241 & 28 & 0.12 & 0.27 & 1.25 \\
\hline CESIUN-137 & 28 & 0.66 & 2.05 & 9.54 \\
\hline PLUTONIUM $239+240$ & 28 & 0.02 & 0.19 & 0.88 \\
\hline PLUTONIUN-238 & 28 & -0.19 & 0.48 & 2.25 \\
\hline RADIUN-226 & 28 & 0.19 & 0.75 & 3.47 \\
\hline RADIUN-228 & 28 & 1.10 & 3.07 & 14.30 \\
\hline STROWTIUM-90 & 28 & 0.37 & 1.72 & 8.02 \\
\hline THORIUN-228 & 28 & 0.20 & 0.47 & 2.19 \\
\hline THORIUH-230 & 28 & 0.69 & 1.00 & 4.67 \\
\hline THORIUN-232 & 28 & 0.31 & 0.42 & 1.98 \\
\hline
\end{tabular}

\subsection{Air Data}

Gross alpha and gross beta data are summarized in Figures B-1 through B-7 of Appendix B and presented in Tables B-1 through B-7 of Appendix B. Nondestructive measurements of gross alpha and gross beta activity were performed on air samples in the EEG laboratory in Carlsbad, New Mexico. Following a minimum of 170 hours of decay, gross alpha activity of air filters averaged $3.38 \mathrm{E}-15 \mu \mathrm{Ci} / \mathrm{ml}$ and gross beta activity averaged $2.03 \mathrm{E}-14$ $\mu \mathrm{Ci} / \mathrm{ml}$. The gross alpha average for EEG samples collected between 1988 and 1991 was $2.13 \mathrm{E}-15 \mu \mathrm{Ci} / \mathrm{ml}$ with a range between $1.35 \mathrm{E}-15 \mu \mathrm{Ci} / \mathrm{ml}$ and $3.15 \mathrm{E}-15 \mu \mathrm{Ci} / \mathrm{ml}$. The gross beta average during the same time period was $2.48 \mathrm{E}-14 \mu \mathrm{Ci} / \mathrm{ml}$ with a range between $1.97 \mathrm{E}-14 \mu \mathrm{Ci} / \mathrm{ml}$ and $3.32 \mathrm{E}-14 \mu \mathrm{Ci} / \mathrm{ml}$. These average activities are consistent with similar data reported in EEG-43 (Kenney et al. 1990), EEG-47 (Kenney and Ballard 1990), EEG-49 (Kenney 1991), EEG-51 (Kenney 1992) and DOE preoperational data 
(Reith et al. 1986; Banz et al. 1987; US DOE, WIPP 1988; US DOE, WIPP 1989; and US DOE, WIPP 1990).

Analytical radiochemistry data obtained from composites of air filter samples are contained in Tables A-1 through A-8 of Appendix A. As discussed previously, the LLD values are calculated using activity data from procedure blanks. The report of thorium decay products at or above the LLD (Table 4) is consistent with previously reported data collected as part of the DOE preoperational baseline program and previously reported EEG data.

\subsection{Water Data}

Radiochemistry data provided by the contractor laboratory are presented in Table A-10 through A-12 of Appendix A. Table 4 is a summary of the number of instances where the WIPP samples exceed or equal the lower limit of detection (LLD or LLD ). The LLDs reported for all water data are those provided by the contractor laboratory and are based upon a standard deviation of instrument background as discussed previously. As additional procedure blanks are provided to the laboratory for analysis, the data base will be used to calculate LLDs based upon the above method derived from the formula in NUREG Guide 4.14 (US NRC 1980). Radionuclides from the uranium, thorium, and radium decay chains were reported equal to or above the $L L D_{c}$, which is consistent with previous work reported by EEG (Kenney et al. 1990; Kenney and Ballard 1990; Kenney 1991; Kenney 1992) and DOE (Reith et al. 1986; Banz et al. 1987; US DOE, WIPP 1988; and US DOE, WIPP 1989). Although Pu-238 and Pu-239+240 in water samples collected during 1992 are reported at activities equal to or greater than the $L L D_{c}$ and in DOE baseline reports (Reith et al. 1986 and Banz et al. 1987), the use of inappropriate procedure blanks could have resulted in artificially low $L L D_{c}$ values as previously discussed. 


\begin{tabular}{|c|c|c|c|c|}
\hline NUCLIDE & $\begin{array}{c}\text { WATER* } \\
\text { SAMPLES } \\
\text { \#LLLD /TOTAL }\end{array}$ & $\begin{array}{c}\text { SOIL \& } \\
\text { SEDIMENT* } \\
\text { \#LLLOC/TOTAL }\end{array}$ & $\begin{array}{c}\text { BIOTA* } \\
\text { SAMPLES } \\
* \rightarrow L L D_{\text {c }} / \text { TOTAL }\end{array}$ & $\begin{array}{c}\text { AIR } \\
\text { SAMPLES } \\
\text { HLLD/TOTAL }\end{array}$ \\
\hline AMERICILN-241 & $0 / 12$ & MA & $0 / 0$ & $0 / 32$ \\
\hline CESIUN-137 & $0 / 12$ & $0 / 2$ & $0 / 0$ & $0 / 32$ \\
\hline GROSS ALPHA & $8 / 12$ & $0 / 2$ & MA & NA \\
\hline GROSS BETA & $8 / 12$ & $0 / 2$ & MA & NA \\
\hline PLUTONILN-238 & $1 / 12$ & $0 / 2$ & $0 / 0$ & $0 / 32$ \\
\hline PLUTONIUN-239+240 & $2 / 12$ & $0 / 2$ & $0 / 0$ & $0 / 32$ \\
\hline RADIUN-226 & $10 / 12$ & MA & MA & $0 / 32$ \\
\hline RADIUM-228 & $2 / 12$ & Ma & MA & $0 / 32$ \\
\hline STRONTIUM-90 & $1 / 12$ & $0 / 2$ & MA & $1 / 32$ \\
\hline TRITIUN & $0 / 7$ & NA & $0 / 0$ & NA \\
\hline THORIUA-228 & $2 / 12$ & $2 / 2$ & MA & $2 / 32$ \\
\hline THORIUM-230 & $5 / 12$ & $2 / 2$ & MA & $1 / 32$ \\
\hline THORIUH-232 & $6 / 12$ & $2 / 2$ & NA & $0 / 32$ \\
\hline URANIUM-233+234 & $11 / 12$ & $2 / 2$ & $M A$ & NA \\
\hline URANIUM-235 & $3 / 12$ & $0 / 2$ & MA & NA \\
\hline URANIUM-238 & $10 / 12$ & $2 / 2$ & NA & NA \\
\hline
\end{tabular}

* = LLD CONTRACTOR REPORTED LONER LIMIT OF DETECTION

NA $=$ NO AMALYSIS

\subsection{Soil and Sediment Data}

Data obtained from radiochemical analysis of soil samples collected approximately 390 meters $(1,279 \mathrm{ft})$ east of the WIPP exhaust shaft and 512 meters $(1,680 \mathrm{ft})$ northeast of WIPP exhaust shaft are contained in Table A-13 of Appendix A. Radionuclides from the 
uranium and thorium decay chains were detected at concentrations above the contractor laboratory's LLD $_{\text {s. }}$.

\subsection{Biota Data}

There were no biota samples collected during 1992 due to budget limitations. Collection of additional biota samples during 1993 is planned.

\subsection{Station A Air Effluent}

Table A-9 of Appendix A contains radiochemical data obtained from analysis of air filters collected from the FAS located in the WIPP underground exhaust system, designated as station A. DOE has not published radiochemical data from FAS filters collected from station A, therefore comparison with other data is not possible.

\subsection{QUALITY ASSURANCE}

Quality assurance (QA) for the purposes of this report is defined as the use of standardized practices and procedures to assure that the highest level of quality is maintained for the data. The QA program consists of an ongoing comparison of analytical data with previous data collected by EEG and other organizations, review of radiochemical quality control, submission of blank samples, recognized reference standards and the use of accepted practices for sample acquisition, handling and analysis.

The procedures used for sample acquisition, handling, and screening are contained in the Environmental Evaluation Group's Environmental Procedures Manual (EPM). This manual is based upon widely recognized procedures such as American Public Health Association (1971), U. S. Environmental Protection Agency (1989), and Corley et al. (1981). 
The Environmental Evaluation Group's contract laboratory for radiochemical analysis of environmental samples maintains a separate QA program. The major components of the contractor program include periodic calibration of counting instruments using standards traceable to the National Institute of Standards Technology, routine determination of chemical yields, and frequent assessment of the quality of reagents. The contractor laboratory participates in the Crosscheck Laboratory Intercomparison Program, which is administered by the U. S. Environmental Protection Agency, and the U. S. Department of Energy Quality Assessment Program.

EEG conducts audits of the procedures, data reduction techniques, quality assurance control plan, quality assurance manual checklist and the annual QA inspection report used by the contract laboratory. In addition the EEG reviews the performance of the contract laboratory in the DOE Quality Assessment Program and the EPA Crosscheck Laboratory Intercomparison Program.

\subsection{CONCLUSIONS AND RECOMMENDATIONS}

The data contained in this report continue the measurement of baseline of radionuclide concentrations in certain critical environmental media on and in the vicinity of the WIPP facility. The data found in this report closely parallel those found in previous reports generated for the WIPP site (Reith et al. 1986; Banz et al. 1987; US DOE, WIPP 1988; US DOE, WIPP 1989; Kenney et al. 1990; Kenney and Ballard 1990; Kenney 1991; Kenney 1992) in terms of preoperational levels of the primordial and fallout radionuclides in the WIPP environment. The average gross alpha concentration in air particulate samples collected by EEG between 1986 and 1991 was $1.81 \mathrm{E}-15 \mu \mathrm{Ci} / \mathrm{ml}$ with a high of $3.15 \mathrm{E}-15$ $\mu \mathrm{Ci} / \mathrm{ml}$ and a low value of $1.53 \mathrm{E}-15 \mu \mathrm{Ci} / \mathrm{ml}$. The average gross alpha concentration in this report was $3.38 \mathrm{E}-15 \mu \mathrm{Ci} / \mathrm{ml}$. The average gross beta concentration reported by $\mathrm{EEG}$ between 1986 and 1991 was $2.51 \mathrm{E}-14 \mu \mathrm{Ci} / \mathrm{ml}$ with a high value of $3.32 \mathrm{E}-14 \mu \mathrm{Ci} / \mathrm{ml}$ reported during 1988 and a low value of $1.97 \mathrm{E}-14 \mu \mathrm{Ci} / \mathrm{ml}$ reported for samples collected 
during 1990. The 1992 gross beta average of data in this report is $2.03 \mathrm{E}-14 \mu \mathrm{Ci} / \mathrm{ml}$. The above gross beta and gross alpha average concentrations reported for 1992 are consistent with previous data reported from the EEG environmental monitoring program.

In order to obtain improved laboratory data quality, EEG will perform analysis of all environmental samples collected after January 1, 1993, in it's Carlsbad radiochemistry laboratory. Revised detection limits will be established for the new measurement systems. However, other problems associated with measuring very low levels of radionuclides in the environment will continue. One purpose of conducting environmental baseline measurements is to better understand these uncertainties before waste arrives at the WIPP facility. 


\section{REFERENCES}

American National Standard Institute, 1992. American national standard performance criteria for radiobioassay. October 30, 1992. ANSI N13.30, American National Standard Institute, New York.

American Public Health Association, 1971. Standard for the examination of water and wastewater. 13th edition, Washington, D.C.

Banz, I., P. Bradshaw, J. S. Cockman, N. T. Fischer, J. K. Prince, A. L. Rodriguez, D. Uhland, 1987. Annual site environmental monitoring report for the Waste Isolation Pilot P sant calendar year 1986. DOE/WIPP-87-002, U.S. Department of Energy.

Bartlett, W. T., 1993. An evaluation of air effluent and workplace radioactivity monitoring at the Waste Isolation Pilot Plant. EEG-52, Environmental Evaluation Group.

Berry, H. A., 1989. An aerial radiological survey of the Waste Isolation Pilot Plant and surrounding area, Carlsbad, New Mexico. AMO-8809, EG\&G Energy Measurements.

Chapman, J. B. 1988. Chemical and radiochemical characteristics of groundwater in the culebra dolomite, southeastern New Mexico. EEG-39, Environmental Evaluation Group.

Chaturvedi, L., and J. K. Channell, 1985. The Rustler formation as a transport medium for contaminated groundwater. EEG-32, Environmental Evaluation Group.

Corley, J. P., D. H. Denham, R. E. Jaquish, D. E. Michels, A. R. Olsen, D. A. Waite, 1981. A guide for environmental radiological surveillance at U. S. Department of Energy installations. DOE/EP-0023, U. S. Department of Energy.

Gonzales, M. M., 1989. Compilation and comparison of the test-hole location surveys in the vicinity of the Waste Isolation Pilot Plant (WIPP) site. SAND 88-1065, Sandia National Laboratories.

Kenney, J., J. Rodgers, J. Chapman, K. Shenk, 1990. Preoperational radiation surveillance of the WIPP project by EEG, 1985-1988. EEG-43, Environmental Evaluation Group.

Kenney, J., and S. C. Ballard, 1990. Preoperational radiation surveillance of the WIPP project by EEG during 1989. EEG-47, Environmental Evaluation Group.

Kenney, J. W., 1991. Preoperational radiation surveillance of the Wlis project by EEG during 1990. EEG-49, Environmental Evaluation Group. 
Kenney, J. W., 1992. Preoperational radiation surveillance of the WIPP project by EEG during 1991. EEG-51, Environmental Evaluation Group.

Liu, B. Y. H., and D. Y. H. Pui, 1980. Aerosol sampling inlets and inhalable particles. Particle Technology Laboratory, University of Minnesota.

Mercer, J. W., 1983. Geohydrology of the proposed Waste Isolation Pilot Plant site, Los Medanos area, southeastern New Mexico. Water-Resources Investigations Report 834016, U. S. Geological Survey.

New Mexico Health and Environment Department, 1989. Regulations governing water supplies. EIB/WSR 2.

New Mexico, State of, and U. S. Department of Energy, 1984. First modification to the July 1, 1981 "Agreement for consultation and cooperation" on WIPP by the State of New Mexico and U. S. Department of Energy.

Ramey, D. S., 1985. Chemistry of Rustler fluids. EEG-31, Environmental Evaluation Group.

Randall, W. S., M. E. Crawley, and M. L. Lyon, 1988. Annual water quality data report for the Waste Isolation Pilot Plant. DOE/WIPP 88-006, U. S. Department of Energy.

Reith, C., K. Prince, T. Fischer, A. Rodriguez, D. Uhland, D. Winstanley, 1986. Annual site environmental monitoring report for the Waste Isolation Pilot Plant calendar year 1985. DOE-WIPP-86-002, U. S. Department of Energy.

Sandia National Laboratories, 1989. Systems analysis, long-term radionuclide transport, and dose assessments, Waste Isolation Pilot Plant (WIPP), southeastern New Mexico. SAND89-0462, Sandia National Laboratories.

Silva, M. K., and J. K. Channell, 1992. Implications of oil and gas leases at the WIPP on compliance with EPA TRU waste disposal standards. EEG-50, Environmental Evaluation Group.

Simpson, H. J., A. L. Herczeg, R. F. Anderson, R. M. Trier, G. G. Mathieu, B. L. Deck, 1985. Mobility of radionuclides in high chloride environments. NUREG/CR4237, U. S. Nuclear Regulatory Commission.

Spiegler, P., 1984. Proposed preoperational environmental monitoring program for WIPP. EEG-26, Environmental Evaluation Group.

Uhland, D. W., and W. S. Randall, 1986. 1986 annual water quality data report for the Waste Isolation Pilot Plant. DOE-WIPP-86-006, U. S. Department of Energy. 
Uhland, D. W., W. S. Randall, and R. C. Carrasco, 1987. 1987 annual water quality data report for the Waste Isolation Pilot Plant. DOE-WIPP-87-006, U. S. Department of Energy.

U.S. Congress, 1979. Department of Energy national security and military applications of nuclear energy authorization act of 1980. Public Law 96-164, 96th Congress.

U.S. Congress, 1993. National defense authorization act for fiscal year 1994. Public Law 103-160, 103rd Congress.

U.S. Department of Commerce, National Oceanic and Atmospheric Administration, 1992. Climatological data annual summary, New Mexico 1992. Volume 96 Number 13.

U.S. Department of Energy, Environmental Measurements Laboratory, November 1990. EML procedures manual. HASL-300.

U.S. Department of Energy, Office of Environmental Restoration and Waste Management, 1990. Final supplement environmental impact statement. DOE/EIS-0026-FS, Volume 2.

U.S. Department of Energy, Waste Isolation Pilot Plant, 1988. Annual site environmental monitoring report for the Waste Isolation Pilot Plant calendar year 1987. DOE/WIPP88-009.

U.S. Department of Energy, Waste Isolation Pilot Plant, 1989. Annual site environmental report for the Waste Isolation Pilot Plant calendar year 1988. DOE/WIPP-89-005.

U.S. Department of Energy, Waste Isolation Pilot Plant, 1990. Waste Isolation Pilot Plant site environmental report for calendar year 1989. DOE/WIPP 90-003.

U.S. Department of Energy, Waste Isolation Pilot Plant, 1991. Waste Isolation Pilot Plant site environmental report for calendar year 1990. DOE/WIPP 91-008.

U.S. Environmental Protection Agency, 1989. National primary and secondary ambient air quality standards. 40 CFR Part 50, U. S. Code of Federal Regulations.

U.S. Environmental Protection Agency, 1990. Environmental radiation protection standards for management and disposal of spent nuclear fuel, high-level and transuranic radioactive wastes. 40 CFR Part 191, U. S. Code of Federal Regulations.

U.S. Environmental Protection Agency, 1991. 40 CFR Part 141, 142 national primary drinking water regulations: radionuclides. Federal Register (18 July) vol. 56, no. 138, p. 33068. 
U.S. Environmental Protection Agency, 1993. 40 CFR Part 191 environmental radiation protection standards for the management and disposal of spent nuclear fuel, high-level and transuranic radioactive wastes. Federal Register (20 December) vol. 58, no. 242, p. 66398-66416.

U.S. Nuclear Regulatory Commission, 1980. Radiological effluent and environmental monitoring at uranium mills. Regulatory Guide 4.14, Revision 1.

U.S. Nuclear Regulatory Commission, Office of Nuclear Reactor Regulation, 1983. Radiological assessment: A textbook on environmental dose analysis. NUREG/CR3332, U. S. Nuclear Regulatory Commission. 

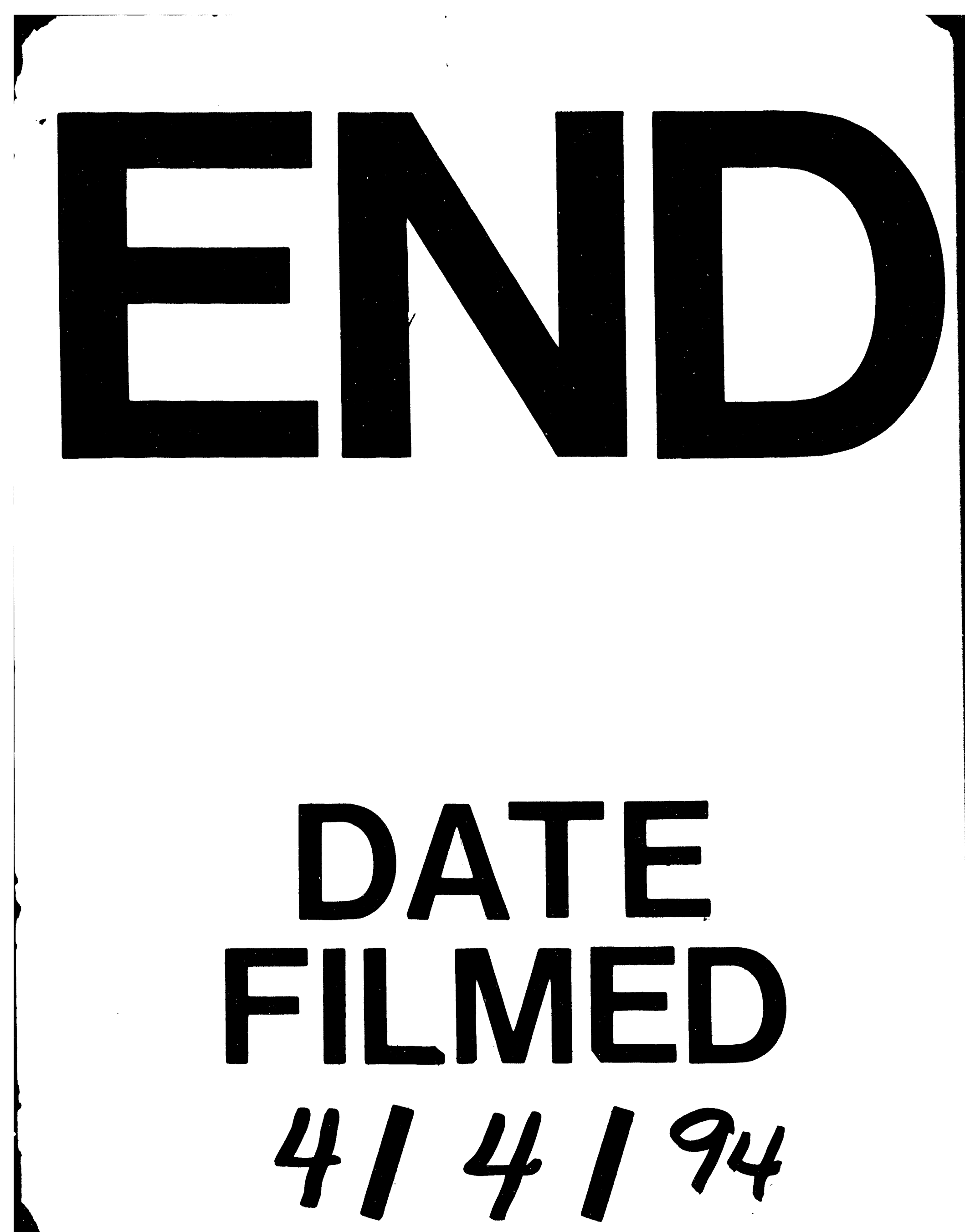
